Urban History, 29, 3 (2002) C $\quad$ 2002 Cambridge University Press Printed in the United Kingdom DOI: $10.1017 /$ S0963926802003097

\title{
Current bibliography of urban history
}

\author{
JOHN SMITH, JOANNA HERBERT and \\ NICOLAS VERDIER
}

This bibliography is a continuation of and a complement to those published in the Urban History Yearbook 1974-91 and Urban History 1992-2001. The arrangement and format closely follows that of previous years. There is an index of towns on p. 509. The list of abbreviations identifies only those periodicals from which articles cited this year have been taken.

\section{General}

Research methods, aids and materials Urban history - definitions and historiography

Urbanization

History, growth and fortunes of individual towns

Portraits of towns: literary, photographic and graphic

\section{Population}

General features of urban populations Natality and mortality

Disease

Migration to, from and between towns

Family and household structure

\section{Physical structure}

Physical and structural characteristics of towns

Physical and structural characteristics of areas within towns

Housing

Environmental conditions

\section{Social structure}

Social structure and characteristics of towns Social organization, clubs and societies Class structure

Social life

Social reform and improvements

Minority groups

Family life

V Economic activity

Urban economic activity
Industry

External trade

Internal trade and services

Working conditions

Labour organization

\section{Communications}

Inter-urban communications

\section{Politics and administration}

Urban politics and administration

Urban politics at national level

Aspects of urban administration

Public utilities

\section{Shaping the urban environment}

Research methods, aids and materials Town planning and environmental control Utopian planning and experiments

Housing improvement

New and expanded towns

\section{Urban culture}

Urban culture and entertainment

Forms of entertainment

Fine arts

Exchange of information

Education

Urban influence on rural areas and the wider world

\section{Attitudes to cities}

Views of the city in literature, graphic and dramatic art 


\section{Journal abbreviations}

\begin{tabular}{|c|c|c|c|}
\hline$A D H$ & $\begin{array}{l}\text { Annales de Demographie } \\
\text { Historique }\end{array}$ & $D A R T$ & $\begin{array}{l}\text { The Devonshire Association, } \\
\text { Report and Transactions }\end{array}$ \\
\hline$A d M$ & Annales du Midi & EcHR & Economic History Review \\
\hline$A d N$ & Annales de Normandie & ECS & Eighteenth Century Studies \\
\hline$A G$ & Australian Geographer & $E E c H$ & Explorations in Economic History \\
\hline AHR & American Historical Review & $E H Q$ & European History Quarterly \\
\hline \multirow[t]{2}{*}{$A H R F$} & Annales Historique de la & $E H R$ & English Historical Review \\
\hline & Revolution Française & EIAL & Estudios Interdisciplinarios de \\
\hline \multirow[t]{2}{*}{ AHSS } & Annales, Histoire, Sciences, & & América Latina y el Caribe \\
\hline & Sociales & EmEUR & Early Medieval Europe \\
\hline$A I$ & The Annals of Iowa & EU & Environment and Urbanization \\
\hline \multirow[t]{2}{*}{$A J A$} & American Journal of & EYH & The East Yorkshire Historian \\
\hline & Archaeology & $F H$ & French History \\
\hline \multirow[t]{2}{*}{ AJES } & American Journal of Economics & $\mathrm{GaH}$ & Gateway Heritage \\
\hline & and Sociology & $\mathrm{GeH}$ & German History \\
\hline$A l B$ & Albion & Gen & Genèses \\
\hline$A L H$ & American Literary History & GHR & The Georgia Historical Review \\
\hline$A l R$ & Alabama Review & $H$ & History \\
\hline \multirow[t]{2}{*}{$A m$} & $\begin{array}{l}\text { The Americas: A Quarterly Review } \\
\text { of Inter-American Cultural }\end{array}$ & $H A H R$ & $\begin{array}{l}\text { Hispanic American Historical } \\
\text { Review }\end{array}$ \\
\hline & History & HAS & Transactions of the Halifax \\
\hline$A m S$ & American Studies & & Antiquarian Society \\
\hline \multirow[t]{2}{*}{ ANYLH } & Afro-Americans in New York Life & $H E$ & History of Education \\
\hline & and History & $H E Q$ & History of Education Quarterly \\
\hline$A p$ & Apollo & $H E \tilde{S}$ & Histoire, Economie et Société \\
\hline$A Q$ & American Quarterly & Hist & The Historian \\
\hline Arch & Archæology & HJ & The Historical Journal \\
\hline$A r t B$ & The Art Bulletin & $H P$ & Hertfordshire's Past \\
\hline ArtH & Art History & $H R$ & Historical Research \\
\hline$A S I$ & Archivo Storico Italiano & HRef & Historical Reflections \\
\hline AtH & Atlanta History & $H U r$ & Histoire Urbaine \\
\hline BArchR & Biblical Archaeology Review & $H W J$ & History Workshop Journal \\
\hline$B A R I$ & BAR International & $\mathrm{HyC}$ & Historia y Cultura \\
\hline$B H M$ & $\begin{array}{l}\text { Bulletin of the History of } \\
\text { Medicine }\end{array}$ & IESHR & $\begin{array}{l}\text { The Indian Economic and Social } \\
\text { History Review }\end{array}$ \\
\hline $\mathrm{BuH}$ & Business History & $\operatorname{InMH}$ & Indiana Magazine of History \\
\hline$B u H R$ & Business History Review & $\operatorname{IrG}$ & Irish Geography \\
\hline C & Cities & IRSH & International Review of Social \\
\hline $\mathrm{Ca}$ & Caravelle & & History \\
\hline$C A$ & Classical Antiquity & $J A E H$ & Journal of American Ethnic \\
\hline CEurH & Contemporary European History & & History \\
\hline$C G$ & The Canadian Geographer & $J A f H$ & The Journal of African History \\
\hline $\mathrm{ChH}$ & Church History & JArchS & Journal of Archaeological Science \\
\hline $\mathrm{ChiH}$ & Chicago History & JAS & Journal of American Studies \\
\hline $\mathrm{CJH}$ & Canadian Journal of History & $J B S$ & Journal of British Studies \\
\hline $\mathrm{ClevH}$ & Cleveland History & $J E c H$ & The Journal of Economic History \\
\hline ContC & Continuity and Change & $J E H$ & Journal of Ecclesiastical History \\
\hline $\mathrm{CSSH}$ & $\begin{array}{l}\text { Comparative Studies in Society } \\
\text { and History }\end{array}$ & $\begin{array}{l}J F H \\
J H\end{array}$ & $\begin{array}{l}\text { Journal of Family History } \\
\text { Journal of History }\end{array}$ \\
\hline CWAAS & Transactions of the Cumberland & $J H G$ & Journal of Historical Geography \\
\hline & and Westmorland Antiquarian & JHS & Jewish Historical Studies \\
\hline & and Archaeological Society & $\operatorname{JInH}$ & The Journal of Interdisciplinary \\
\hline $\mathrm{CWH}$ & Civil War History & & History \\
\hline
\end{tabular}




\begin{tabular}{|c|c|c|c|}
\hline \multirow[t]{2}{*}{ JISHS } & Journal of the Illinois State & PHR & Pacific Historical Review \\
\hline & Historical Society & $\mathrm{RadH}$ & Radical History \\
\hline \multirow[t]{2}{*}{$J L A C S$} & Journal of Latin American & $R A m H$ & Reviews in American History \\
\hline & Cultural Studies & RBH & Revista Brasileira de Historia \\
\hline JLS & The Journal of the London Society & $R B u$ & Records of Buckinghamshire \\
\hline JMEMS & $\begin{array}{l}\text { Journal of Medieval and Early } \\
\text { Modern Studies }\end{array}$ & RGSM & $\begin{array}{l}\text { Geographical: The Royal } \\
\text { Geographical Society Magazine }\end{array}$ \\
\hline$J M H$ & Journal of Medieval History & RH & Revue Historique \\
\hline JMHRS & $\begin{array}{l}\text { Journal of the Merioneth Historical } \\
\text { and Record Soceity }\end{array}$ & RHEF & $\begin{array}{l}\text { Revue d'Histoire de l'Eglise de } \\
\text { France }\end{array}$ \\
\hline JMisH & Journal of Mississippi History & RHR & Radical History Review \\
\hline JModH & The Journal of Modern History & $R N$ & Revue du Nord \\
\hline JNH & Journal of Negro History & SC & Studia Celtica \\
\hline$J P H$ & Journal of Policy History & SCHM & South Carolina Historical \\
\hline$J R S$ & The Journal of Religious History & & Magazine \\
\hline JSAS & $\begin{array}{l}\text { Journal of Southern African } \\
\text { Studies }\end{array}$ & $\mathrm{SecHR}$ & $\begin{array}{l}\text { Scandinavian Economic History } \\
\text { Review }\end{array}$ \\
\hline JSH & The Journal of Southern History & SH & Social History \\
\hline $\mathrm{JSocH}$ & Journal of Social History & SouH & Southern History \\
\hline$J S p H$ & Journal of Sport History & $S p H R$ & Sport History Review \\
\hline$J U A$ & Journal of Urban Affairs & SSH & Social Science History \\
\hline$J U H$ & Journal of Urban History & SSJ & The Social Science Journal \\
\hline$J W$ & Journal of the West & ST & Sky and Telescope \\
\hline JWH & Journal of Women's History & SuffIAH & Proceedings of the Suffolk \\
\hline KH & Kansas History & & Institute of Archaeology and \\
\hline $\mathrm{LaH}$ & Louisiana History & & History \\
\hline LeiH & Leicestershire Historian & SW & Science World \\
\hline LH & Labor History & SWHQ & Southwestern Historical Quarterly \\
\hline LJ & The London Journal & $T C$ & Technology and Culture \\
\hline$M d H M$ & Maryland Historical Magazine & $T H Q$ & Tennessee Historical Quarterly \\
\hline $\operatorname{MexS}$ & Mexican Studies & ThS & Transactions of the Thoroton \\
\hline MHR & Michigan Historial Review & & Society of Nottinghamshire \\
\hline MisHR & Missouri Historical Review & TLAHS & The Leicestershire Archaeological \\
\hline MoA & Moyen Age & & and Historical Society \\
\hline$N$ & Nature & & Transactions \\
\hline NCHR & North Carolina Historical Review & TT & Third Text \\
\hline $\mathrm{NeH}$ & Nebraska History & TWPR & Third World Planning Review \\
\hline NG & National Geographic & UAR & Urban Affairs Review \\
\hline NMHR & New Mexico Historical Review & UH & Urban History \\
\hline NMS & Nottingham Medieval Studies & UHQ & Utah Historical Quarterly \\
\hline $\mathrm{OAHMH}$ & Organization of American & $V$ & Viator \\
\hline & Historians Magazine of History & $V S$ & Victorian Studies \\
\hline $\mathrm{OH}$ & Oral History & WarH & Warwickshire History \\
\hline $\mathrm{OhH}$ & Ohio History & WH & Washington History \\
\hline $\mathrm{OHQ}$ & Oregon Historical Quarterly & WHQ & Western Historical Quarterly \\
\hline $\mathrm{OHR}$ & Oregon History Review & $W M Q$ & The William and Mary Quaarterly \\
\hline $\mathrm{PaP}$ & Past and Present & WS & Wiltshire Studies \\
\hline $\mathrm{PenH}$ & Pennsylvania History & YAJ & Yorkshire Archæological Journal \\
\hline PenMHB & Pennsylvania Magazine of History & YVS & Yad Vashem Studies \\
\hline & and Biography & $Z f K$ & Zeitschrift für Kunstgeschichte \\
\hline
\end{tabular}




\section{General}

\section{Research methods, aids and materials}

1 ALLEN L, A new Portsmouth guide; 1790 ... its buildings, charitable foundations, fairs, markets, playhouse, and assembly-room. Portsmouth: Realvision Imagining Solutions Ltd 2001. 1 computer optical disc, in HTML, JPEG and GIF formats.

2 ALLEN L, The history of Portsmouth 1801: containing its origin, progressive improvements, and present state of its public buildings: naval, military, civil, and commercial establishments, and institutions. Portsmouth: Realvision Imagining Solutions Ltd 2001. 1 computer optical disc, in HTML, JPEG and GIF formats.

3 ALLEN L, The history of Portsmouth 1802: containing its origin, progressive improvements, and present state of its public buildings: naval, military, civil, and commercial establishments, and institutions. Portsmouth: Realvision Imagining Solutions Ltd 2001. 1 computer optical disc, in HTML, JPEG and GIF formats.

4 ALLEN L, The history of Portsmouth 1809: containing its origin, progressive improvements, and present state of its public buildings: naval, military, civil, and commercial establishments, and institutions. Portsmouth: Realvision Imagining Solutions Ltd 2001. 1 computer optical disc, in HTML, JPEG and GIF formats.

5 ALLEN L, The history of Portsmouth 1817: containing a full and enlarged account of its ancient and present state. Portsmouth: Realvision Imagining Solutions Ltd 2001. 1 computer optical disc, in HTML, JPEG and GIF formats.

6 ALLEN L, The Portsmouth guide 1822. Portsmouth: Realvision Imagining Solutions Ltd 2001. 1 computer optical disc, in HTML, JPEG and GIF formats.

7 ALLEN L, The Portsmouth guide 1823. Portsmouth: Realvision Imagining Solutions Ltd 2001. 1 computer optical disc, in HTML, JPEG and GIF formats.

8 CORBOZ A, Le territoire comme palimpseste et autres essais. Besançon: l'Imprimeur 2001. pp 288, il.

9 RONCAYOLO M, Lectures de villes: formes et temps. Marseille: Parenthèses 2001. pp 392, il.

10 WARDLEY P ed, Bristol historical resource. Bristol: U of the West of England 2000. 1 computer optical disc, in HTML, JPEG and GIF formats.

\section{Research methods}

11 OPPETIT C ed, Des archives de l'architecture aux archives de la ville: table ronde tenue aux Archives nationales les 18 et 19 juin 1998. Paris: Direction des Archives de France 2001. pp 192.

Printed documentary sources

12 BONVARD F, Chroniques de Genève. 1, Des origines à 1504. Geneva: Droz 2001.

13 CARLIN M, London and Southwark inventories 1316-1650: a handlist of extents for debts. London: Centre for Metropolitan History, Institute of Historical Research, U of London 1997. pp xxvii +103.

14 CARR DR ed, The first general entry book of the city of Salisbury, 1387-1452. Trowbridge: Wiltshire Record Society 2001. pp xxxvi +316.

15 PINKS WJ, The history of Clerkenwell. Facsimile of 2nd ed. 1881. London: Francis Boutle 2001. pp xx +800 , il.

Maps and plans

16 DUCOUDRAY E et al, Atlas de la Révolution française, Paris. Paris: Ecole des Hautes Etudes en Sciences Sociales 2001. pp 132, il.

17 GRONIM SS, Geography and persuasion: maps in British colonial New York. WMQ LVIII 2 (2001) 373-402. 
Bibliographies Institute of Irish Studies, Queens U of Belfast 1998. pp vii + 158, il.

19 DUNNIGAN BL, 'The prettiest settlement in America': a select bibliography of early Detroit through the war of 1812. MHR 27 (2001) 1-20.

20 MERCIER P, 60 années de recherches sur l'histoire de Sèvre et autres lieux. Paris: Gutemberg XXIe siècle 2001. pp 158.

21 SHI M, Secondary sources in Chinese urban history: a topical bibliography. JUH 271 (2000) 114-24.

Archives - descriptions and examples

22 MILLER S ed, Charters of the new minster, Winchester. Oxford: Oxford UP 2001. pp lxvii +244 .

\section{Urban history - definitions and historiography}

23 LOYER F ed, Ville d'hier, ville d'aujourd'hui: regards croisés sur la ville. Paris: Fayard 2001. pp 300.

24 SCHAUB MK, Les 850 ans de Moscou: une historiographie novatrice? HUr 4 (2001) $151-60$.

Urban history, definitions and aims

25 JANSEN H, The construction of an urban past: narrative and system in urban history. Berg 2001.

\section{Urbanization} Cambridge UP 2000.

Theory of urbanization

27 KLENIEWSKI N, Cities, change, and conflict: a political economy of urban life, 2nd ed. Belmont: Wadsworth, Thompson Learning 2002.

Empirical studies of urbanization - general MARLEY D, Historical cities of America: an illustrated encyclopaedia. Oxford: Oxford UP 2001.

29 TARDY AJ, De telo à amphitria. 3-2. Ollioules: Ed. de la Nerthe 2000. pp 220, il.

30 ABADIE-REYNAL C, Séleucie-Zeugma et Apamée sur l'Euphrate: étude d'un cas de villes jumelles dans l'Antiquité. HUr 3 (2001) 7-24.

31 ALSTON R, The city in Roman and Byzantine Egypt. London: Routledge 2001.

32 BEDON R, Atlas des villes, bourgs, villages au passé romain de France. Paris: Picard 2001. pp 352, il.

33 BELAYCHE N ed, Rome, la ville et le prince: programme de Capes, agrégation d'histoire. Rennes: UP Rennes 2001. pp 350.

34 BENNETT J, Towns in Roman Britain. Princes Risborough: Shire 2001.

35 BURNS T \& EADIE JW eds, Urban centers and rural contexts in late antiquity. East Lansing: Michigan State U 2001.

36 CANDIDO DA SILVA M, Les cités et l'organisation politique de l'espace en Gaule mérovingienne au VIe siècle. HUr 4 (2001) 83-104

37 CARROLL M \& CARROLL C, Exploring ancient cities of the bible. Cook Communications Ministries International 2001. 
38 CORBIER P, Rome ville et capitale: de la fin de la République à la fin des Antonins. Paris: Sedes 2001. pp 224.

39 DENIAUX E, Rome de la cité-État à l'Empire: institutions et vie politique aux $2 e$ et 1er siècle. Paris: Hachette-éducation 2001. pp 256.

40 GREENBERG R, Early urbanizations in the Levant: a regional narrative. New York/ Leicester: Leicester UP 2001.

41 GUIRAUD H ed, Pallas. 55, la ville de Rome sous le Haut-Empire: nouvelles connaissances, nouvelles réflexions: colloque, Rome, École française de Rome et Société des Professeurs d'Histoire ancienne de l'Université de Rome, 5-8 mai 2001. Toulouse: PU du Mirail 2001. pp 319 .

42 HOOK J, Lost cities. Austin: Raintree Steck-Vaughn 2001.

43 KAPLAN M ed, Rome, ville et capitale: de César à Commode. Rosny sous Bois: Bréal 2001. pp 192.

44 KUNST C, Römische wohn- und lebenswelten. quellen zur geschichte der römischen stadt. Darmstadt: Wissenschaftliche Buchgesellschaft 2000.

45 LAVAN L \& BOWDOIN W, Recent research in late-antique urbanism. Portsmouth: Journal of Roman Archaeology 2001.

46 LE BOHEC Y ed, Rome, ville et capitale: de César à la fin des Antonins. Paris: Ed. du temps 2001. pp 416.

47 LE BOHEC Y, Urbs, Rome de César à Commode: histoire d'une ville et d'une capitale. Paris: Ed. du temps 2001. pp 192.

48 LEFEBVRE S, Rome, ville et capitale, de César à la fin des Antonins. Paris: Vuibert 2001. pp 432.

49 LEICK G, Mesopotamia: the invention of a city. London: Allen Lane 2001.

50 LÜCKE S, Syngenei: epigraphisch-historische studien zu einem phänomen der antiken griechischen diplomatie. Frankfurt: M Clauss 2000.

51 REMY B et al eds, Rome, ville et capitale, de César à Commode: la ville et le prince. Paris: Ellipses-Marketing 2001. pp 303.

52 WOOLFE G, Becoming Roman: the origins of provincial civilization in Gaul. Cambridge: Cambridge UP 2000.

Medieval and early modern (-1800)

53 ANDIA B, Les enceintes de Paris: limites et urbanisation. Paris: Action artistique de la ville de Paris 2001. pp 264, il.

54 ATTREED LC, The king's towns: identity and survival in late medieval English boroughs. New York: P Lang 2001.

55 BARRAL I ALTET X, Le monde roman: villes, cathédrales et monastères. Berlin: Taschen 2001 (réed). pp 237, il.

56 BORSAY P \& PROUDFOOT LJ, Provincial towns in early modern England and Ireland: change, convergence, and divergence. Oxford: Oxford UP 2001.

57 BROGIOLO GP \& GAUTHIER N, Towns and their territories between late antiquity and the early middle ages. Leiden/Boston: Brill 2000.

58 CADINU M, Urbanistica medievale in Sardegna. Rome: Bosignori 2001.

59 CRETE L, La Rochelle au temps du grand siège, 1627-1628. Paris: Perrin 2001. pp 336.

60 DUPRONT A, Genèses des temps modernes: Rome, les réformes et le nouveau monde. Paris: Seuil 2001. pp 408

61 EPSTEIN SR, Town and country in pre-modern Europe. Cambridge: Cambridge UP 2001.

62 FOUACE J, Cherbourg: port aux princes. Cherbourg: Isoëte 2001. pp 239, il.

63 FRECHE G, Puylaurens, une ville huguenote en Languedoc: deux siècles (1595-1815) de mutations économiques, sociales et culturelles. Toulouse: Privat 2001. pp 400.

64 GAMICHON L, Napoléon et les Lyonnais: 1779-1815. Lyon: Bellier 2001. pp 342, il.

65 GARCIN J-C, Grandes villes méditerranéennes du monde musulman médieval. Rome: École française de Rome 2000.

66 JOHNSON E, Medieval towns and country life. London: Watts 2001. 
KERR D, Medieval fortress. London: Watts 2001.

68 LANGLOIS GA, Histoire d'un quartier de Paris: de la Salpétrière à la Bibliothèque nationale de France. Paris: Somogy 2001. pp 141, il.

69 LE MENE M, Villes et campagnes de l'ouest au Moyen Âge. Nantes: Ouest éditions 2001. pp 320.

70 LEGUAY JP \& LARDIN P, La ville médiévale en-deçà et au-delà de ses murs: mélanges JeanPierre Leguay. Mont-Saint-Aignan: Publications de l'Université de Rouen 2000.

71 LIEBESCHUETZ JHWG, The decline and fall of the Roman city. Oxford: Oxford UP 2001.

72 LOMAS K \& CORNELL T eds, Cities and urbanization in ancient Italy. Leiden: Brill 2001.

73 MACLEAN G, LANDRY D \& WARD J eds, The country and the city revisited. Cambridge: Cambridge UP 1999.

74 MONNIER P, Venise au XVIIIe siècle. Bruxelles: Complexes 2001 (réed). pp 308.

75 MULLER C, Colmar au XVIIIe siècle. Strasbourg: Coprur 2000. pp 176, il.

76 PERROT JC, Genèse d'une ville moderne: Caen au 18e siècle. Paris: École des Hautes Études en Sciences Sociales 2001. 4 vols. pp 1162 , il.

77 ROMAN A, Saint-Malo au temps des négriers. Paris: Karthala 2001. pp 357, il.

78 TITTLER R, Townspeople and nation: English urban experience, 1540-1640. Stanford: Stanford UP 2001.

79 WENSKY M, Moers. die geschichte der stadt von der frühzeit bis zur gegenwart. Cologne: Böhlau 2000.

Modern (1800-)

80 ABROMAVICI P \& MOURNAUD C, Un rocher bien occupé: Monaco pendant la guerre 1939-1945. Paris: Seuil 2001. pp 372.

81 AUBIN D et al, Dieppe 1900-2000: un siècle de vie. Fécamp: Ed. des Falaises 2000. pp 128, il.

82 BAGNASCO A \& GALÈS PL eds, Cities in contemporary Europe. Cambridge: Cambridge UP 2000.

83 BAUSSY A. Cannes, ma ville: au XIXe siècle et à la belle époque. Spéracedes: TAC Motifs 2001. pp 131, il.

84 BERNARD G, Toulouse: métamorphoses du siècle. Portet-sur-Garonne: Empreinte 2001. pp 136, il. BLIN P, Orly ou la chronique d'une ville en mouvement. Paris: Eds de l'Epure 2001. pp 72. BOIRY P \& SALVATORE G, Paris sous les bombes: Auteuil, septembre 1943. Paris: L'Harmattan 2000. pp 260.

87 BOITEAU P, Honfleur et son canton au quotidien: 1939-1945. Honfleur: Ed. de la Lieutenance 2000. pp 250, il.

88 BRIGOULEIX B, 1961-1989 Berlin. Paris: Tallandier 2001. pp 300.

89 COINTET JP, Paris, 1940-1944. Paris: Perrin 2001. pp 139.

90 DEBRET JB, Rio de Janeiro: la ville métisse. Paris: Chandeigne 2001. pp 196, il.

91 DESQUENNE JP et al, Caen 1900-2000: un siècle de vie. Fécamp: Ed. des Falaises 2001. pp 196, il.

92 DINESEN AW, Paris sous la Commune. Paris: M. de la Maule 2001. pp 340.

93 GIOLITTO P, Grenoble, 1940-1944. Paris: Perrin 2001. pp 493, il.

94 GUGLIELMETTI D, Gonesse au XXe siècle: un bourg devient une ville. Saint-Ouen1'Aumone: Valhermeil 2000. pp 255, il.

95 Hanoï. Paris: Recherches 2001.pp 352.

96 IOFFE G, The environs of Russian cities. Lampeter: Edwin Mellen P 2000.

97 LARTIGUE J, Autrefois Capbreton. Biarritz: Atlantica 2001.

98 LESACHER A et al, Le Mans hier et aujourd'hui. Rennes: Ouest-France 2000. pp 125, il.

99 MELLOT P, Paris. Paris: Ed. du Lodi 2001. pp 288, il.

100 RONCAYOLO M ed, Histoire de la France urbaine. 5, La ville aujourd'hui: mutations urbaines, décentralisation et crise du citadin. Paris: Seuil 2001 (réed). pp 928.

101 SALLENAVE LH, Un siècle à Pau et en Béarn. Biarritz: Atlantica 2000. pp 420. 
102 SALQUAIN P \& LAMOULIATTE-CLAVERIE R, Autrefois Bayonne: la collection Robert Lamouliatte-Claverie. Biarritz: Atlantica 2001. pp 55, il.

103 SAUVY A, Chamonix d'un siècle à l'autre. Paris: Artaud 2001. pp 628.

104 SIMMAT G, Châtellerault: histoire illustrée de la ville aux XIXe et XXe siècles. Barbentane: Equinoxe 2001. pp 128, il.

105 SOUZA R, Nice, capitale d'hiver: le développement urbain de Nice au début du XXe siècle. Nice: Serre 2001. pp 256, il.

106 TROCME H, Chicago 1890-1930: audaces et débordements. Paris: Autrement 2001. pp 180.

107 WALLE AV, Evreux et l'Eure pendant la guerre: 1939-1945. Evreux: C Hérissey 2000. pp. 219.

\section{History, growth and fortunes of individual towns}

This section is arranged alphabetically by the name of the town

108 BELLET ME \& FLORENSON P, La cité d'Aigues-Mortes. Paris: Eds du Patrimoine 2001. pp 56, il.

109 VRETTOS T, Alexandria: city of the western mind. New York: Free Press 2001.

110 DUSEVEL FH, Histoire de la ville d'Amiens: depuis les Gaulois jusqu'en 1830. 1. Paris: Livre d'Histoire-Lorisse 2001 (réed). pp 566.

111 DUSEVEL FH, Histoire de la ville d'Amiens: depuis les Gaulois jusqu'en 1830. 2. Paris: Livre d'Histoire-Lorisse 2001 (réed). pp 558, il.

112 MAK G, Amsterdam. Cambridge, Mass: Harvard UP 2000.

113 HOLMES P, Antrim town \& county. Donaghadee, Northern Ireland: Cottage Publications 1999. pp 91, il.

114 JUDENNE C, Mémoire d'Argenteuil. Paris: Larousse 2001. pp 176, il.

115 ANDRE-SALVINI B, Babylone. Paris: PUF 2001. pp 127, il.

116 WARTBURG BV ed, Basel, Geschichte einer städtischen Gesellschaft. Basel: ChrisophMerian Verlag 2000.

117 ASCHERSON N, Berlin: a century of change. Munich/London: Prestel in association with AKG 2000. pp 120, il.

118 LARGE DC, Berlin. London: Allen Lane 2001. pp xxvii + 706, il.

119 BEWDLEY HISTORICAL RESEARCH GROUP, Bewdley in its golden age. Bewdley: Bewdley Historical Research Group 1999. pp 168, il.

120 LEATHER P, A brief history of Birmingham. Studley: Brewin Books 2001. pp viii +60 , il.

121 ENGLAND M \& HADLEY P eds, Bodmin 1901-2000: a century of memories. Bodmin: Bodmin Books 2000. pp 75, il.

122 ETIENNE R et al ed, Histoire de Bordeaux. Toulouse: Privat 2001 (new ed). pp 412, il.

123 JULLIAN C, Histoire de Bordeaux depuis les origines jusqu'aux guerres de religion. 1, Des origines au XVIe siècle. Belin-Beliet: Princi Neguer 2001. pp 339, il.

124 O'CONNOR TH, The hub: Boston past and present. Northeastern UP 2001.

125 WARNER SB Jr, Greater Boston: adapting regional traditions to the present. Philadelphia: U of Pennsylvania P 2001.

126 BROOMFIELD MA, Bournville then and now. York: W Sessions 2001. pp x + 158, il.

127 GALLIO P \& HENWOOD A, Histoire de Brest. Paris: JP Gisserot 2001. pp 128.

128 HARRIS P \& KNIGHT N eds, Post-war Bristol 1945-1965: twenty years that changed the city. Bristol: Bristol Branch of the Historical Association 2000. pp 144, il.

129 ELMHORN C, Brussels, a reflexive world city. Stockholm: Almqvist \& Wiksell 2001.

130 YOUNG B, Bude's maritime heritage: past and present. Bude: Bill Young 2001. pp 115, il.

131 HENRY G, Les belles dates du Caen de jadis. Condé sur Noireau: C Corlet 2001. pp 112, il.

132 HENRY G, Les célèbres de Caen. Caen: Maître Jacques 2000. pp 240, il.

133 WHITEHEAD J, The growth of Camden Town AD 1800-2000. London: J Whitehead 2000. pp 231, il. 
134 EALES R, Vikings, monks and the millennium: Canterbury in about 1000 A.D.: lectures delivered to a meeting of the Canterbury Archaeological Society on 30th March 2000. Canterbury: Canterbury Archaeological Society 2000. pp 42, il.

135 GUILAINE J \& FABRE D ed, Histoire de Carcassonne. Toulouse: Privat 2001 (new ed). pp 322, il.

136 BESSE JP, Chantilly et Noyon dans l'histoire. Chantilly: JP Besse 2001. pp 434.

137 DEW SH, The queen city at war: Charlotte, North Carolina during World War II, 1939-1945. Lanham, Md: UP of America 2001.

138 SELKIRK R, Chester-le-Street and its place in history. Tyne and Wear: Northern Archaeology Group 2001. pp viii + 536, il.

139 ANDERSON J, City watch: discovering the uncommon Chicago. U of Iowa P 2001.

140 COWAN D, Great Chicago fires: historic blazes that shaped a city. Chicago: Lake Claremont 2001.

141 D'ERAMO M, The pig and the skyscraper: Chicago. a history of our future. London: Verso 2001.

142 HEISE K, Chicago the beautiful: a city reborn. Chicago: Bonus Books 2001.

143 FITCH CR \& GOLDMAN N, New light from ancient Cosa: classical Mediterranean studies in honor of Cleo Rickman Fitch. New York: P Lang 2001.

144 COLLINSON D, The chronicles of Dartmouth: an historical yearly log, 1854-1954. Dartmouth: Richard Webb 2000. pp 296, il.

145 BAK R, Detroit: across three centuries. Chelsea, Mich: Sleeping Bear 2001.

146 LIMOGES E, Detroit and 300 years of metropolitan growth. Detroit: Southeast Michigan Council of Governments 2001.

147 POREMBA DL, Detroit in its world setting: a three hundred year chronology, 1701-2001. Detroit: Wayne State UP 2001.

148 WOODWARD AM, This is Detroit, 1701-2001. Detroit: Wayne State UP 2001.

149 PUGH RB, A history of Devizes. Trowbridge: Wiltshire County Council and Kennet District Council 2001. pp viii +280 , il

150 BAZIN JF, Histoire de Dijon. Paris: JP Gisserot 2001. pp 128, il.

151 BOYER R et al, Draguignan, 2.000 ans d'histoire. La Tour d'Aigues: Ed. de l'Aube 2001. pp 192, il.

152 CLAYTON A \& RUSSELL A eds, Dresden, a city reborn. Berg 2000.

153 MARX H \& WEBER GJM, Dresden in the ages of splendour and enlightenment. U of Washington P 2000.

154 KOSTICK C, The Easter Rising: a guide to Dublin in 1916. Dublin: O'Brien Press 2000, pp 141, il.

155 O'FARRELL M, A walk through rebel Dublin 1916: a guide to some of the locations where history was made in April 1916. Cork/Dublin: Mercier P 1999. pp 128, il.

156 DUFOUR A, Histoire de Genève. Paris: PUF 2001 (3e ed mise à jour). pp 128.

157 BURROWES J, Great Glasgow stories. Edinburgh: Mainstream 1998. pp 254.

158 MAVER I, Glasgow. Edinburgh: Edinburgh UP 2000. pp xiii + 306, il.

159 ASLET C, Greenwich millennium: the 2000-year story of Greenwich. London: Fourth Estate 1999. pp 255, il.

160 ASLET C, The story of Greenwich. Cambridge, Mass: Harvard UP 2000.

161 JENNINGS C, Greenwich: the place where days begin and end. London: Little Brown \& Co. 1999. pp 242.

162 PAPIN P, Histoire de Hanoï. Paris: Fayard 2000.

163 SHIELDS P, Essential Islington: from Boadicea to Blair. Stroud: Sutton 2000. pp 224.

164 GARIN J, Histoire d'Ivry sur Seine des origines à nos jours. Paris: Livre d'Histoire-Lorisse 2001. pp 824, il.

165 PERRY P comp, Jarrow. Stroud: Tempus 1999. pp 95.

166 BALIVET M, Konya: la ville des derviches tourneurs. Paris: CNRS éditions 2001. pp 128, il.

167 GARBETT M, Lincoln at war, 1944-1966. Shepperton: Ian Allan 1999. pp 175, il. 
168 MACKEY B, Lisburn: the town and its people, 1873-1973. Belfast: Blackstaff 2000. pp x + 165 , il.

169 BELCHEM J, Merseypride: essays in Liverpool exceptionalism. Liverpool: Liverpool UP 2000.

170 ACKROYD P, London: the biography. London: Chatto and Windus 2000. pp xxiii +822 .

171 INWOOD S, A history of London. London: Papermac 2000. pp xxii + 1111, il.

172 KYNASTON D, The city of London. Vol. 4: A club no more 1945-2000. London: Chatto \& Windus. pp 886, il.

173 RICHARDSON J, The annals of London: a year-by-year record of a thousand years of history. London: Cassell 2000. p 408, il.

174 SCHNEER J, London 1900: the imperial metropolis. London: Yale UP 1999. pp ix + 336, il.

175 SHEPPARD FHW, London: a history. Oxford: Oxford UP 1998. pp 442.

176 VALENTE K, TRIMBLE S \& TRIMBLE C, The amateur historian's guide to medieval and Tudor London. London: Capital Books 2001.

177 HOSTETTLER E, The Isle of Dogs 1066-1918: a brief history. London: Island History Trust 2000. pp 120, il.

178 NEYRET R, Lugdunoscope: tour de Lyon en 80 chapitres. Lyon: Eds lyonnaises d'Art et d'Histoire 2000. pp 244, il.

179 ILLADES C \& RODRÍGUEZ K, Institciones y ciudad: ocho estudios históricos sobre la ciudad de México. Jalapa: Unidad Obrera y Socialista 2000.

180 AMOS D \& HARRIET E, Cotton city: urban development in antebellum Mobile. Tuscaloosa: U of Alabama P 2001.

181 CHOLVY G ed, Histoire de Montpellier. Toulouse: Privat 2001 (new ed). pp 440, il.

182 WISMES A, Les grandes heures de Nantes. Paris: Perrin 2001 (réed). pp 288, il.

183 PHILLIPS G, Newcastle: then and now: showing Newcastle upon Tyne in the 1950's and 1960's compared with the present day. Durham: GP Electronic Services 1997. pp 72, il.

184 COLTON CE ed, Transforming New Orleans and its environs. Pittsburgh: U of Pittsburgh P 2000.

185 COWAN WG, New Orleans yesterday and today: a guide to the city. Baton Rouge: Louisiana State UP 2001.

186 ROSE J, New York sawed in half: an urban historical. New York: St Martin's 2001.

187 LINETHAL ET, The unfinished bombing: Oklahoma city in American history. Oxford: Oxford UP 2002.

188 VANNIER S, Orléans au fil de son histoire. Chambray les Tours: CLD 2001.pp 127, il.

189 GOODWIN J, Otis: giving rise to the modern city. Chicago: Ivan Dee 2001.

190 COLE R, A traveller's history of Paris. Moreton-in-Marsh: Windrush 1999. pp x + 308, il.

191 COMBEAU Y, Histoire de Paris. Paris: PUF 2001 (2nd ed). pp 128.

192 DURANTE C et al, 2001, l'Île Saint-Louis. Courbevoie: Durante 2001. pp 224, il.

193 MANSEL P, Paris between empires, 1841-1852. London: John Murray 2001. pp ix + 559, il.

194 VAREJKA P, Paris: brève histoire de la capitale. Paris: Parigramme 2000. pp 153.

195 WISER W, The twilight years: Paris in the 1930s. London: Robson Books 2001. pp 292, il.

196 HARDIE M, Penzance. Penzance: Penzance Town Council 2000. pp 117, il.

197 NASH GB, First city: Philadelphia and the forging of historical memory. Philadelphia: U of Pennsylvania P 2001.

198 HAUMONTE JD, Plombières: ancien et moderne. Nîmes: Lacour 2001 (réed). pp 423.

199 ABВОTT C, Greater Portland: urban life and landscape in the Pacific Northwest. Philadelphia: U of Pennsylvania P 2001.

200 HATCHER CJ, The history of Richmond, north Yorkshire, from earliest times to the year 2000. Pickering: Blackthorn 2000. pp 252, il.

201 BORIAUD JY, Histoire de Rome. Paris: Fayard 2001. pp 420.

202 GREGOROVIUS F, History of the city of Rome in the middle ages: 1421-1503 A.D. Trans. A. Hamilton. Italica P 2001. 
203 LANÇON B, Rome in late antiquity: everyday life and urban change, AD 323-609. Edinburgh: Edinburgh UP 2000. pp 185.

204 TARPIN M, Roma fortunata: identité et mutation d'une ville éternelle. Gollion: Infolio 2001. pp 288, il.

205 PELLETIER Y, Saint-Brieuc. Saint-Malo: Cristel 2001. pp 48, il.

206 TOBIAS HJ \& WOODHOUSE CE, Santa Fe: a modern history, 1890-1990. Albuquerque: U of New Mexico P 2001.

207 BINNS J, The history of Scarborough: from earliest times to the year 2000. Pickering: Blackthorn P 2001. pp $\mathrm{x}+459$, il.

208 DRINKWATER P, Soliloquies of old Shipston: being to some extent a history of the market town of Shipston upon Stour in the county of Worcester. Shipston-on-Stour: P Drinkwater 1979. pp 157, il.

209 ANKINS J comp, Sidmouth: the war years, 1939-1949. Sidmouth: J Ankins 2001. pp iii + 75 , il.

210 HACKWOOD FW, Some records of Smethwick. Studley: Brewin 2001. pp 127.

211 WHITBY M, Sparta. Edinburgh: Edinburgh UP 2001.

212 ABLEY B comp, Spennymoor remembered. Spennymoor: ARB Book 2 2000. pp 128, il.

213 DODDS GL, A history of Sunderland. Sunderland: Albion 2001. pp 160, il.

214 TEDDER A, Sunderland east end revisited. Sunderland: People's P 2000. pp 72, il.

215 RESTIFO G, Tourism and the history of Taormina, Sicily, 1750-1950. New York/ Lampeter: Edwin Mellen P 2000. pp iii + 284.

216 GRIFFITHS G, History of Teignmouth. Bradford on Avon: ELSP 2001. pp 160, il.

217 DAVISON M, Tolworth remembered. Reigate: M Davison 2001. pp 64, il.

218 CHAMBERS D \& FLETCHER J, Venice: a documentary history, 1450-1630. Toronto: U of Toronto P 2001.

219 LAW JE, Venice and the Veneto in the early renaissance. Aldershot: Ashgate 2000.

220 ZORZI A, La République du lion: histoire de Venise. Paris: Perrin 2001. pp 466.

\section{Portraits of towns - literary, photographic and graphic}

This section is arranged alphabetically by the name of the town

Literary and personal reminiscences

221 DEMOUGIN J, J'étais à Alger. Paris: Trésor du Patrimoine 2001. pp 132.

222 STANLEY LT, Vignettes and memories: reflections from a Cambridge drawing room. London: Robson 2001. pp 256, il.

223 LEE B comp, Cardiff voices. Stroud: Tempus 2000. pp 128, il.

224 HOURDEL C, De Gaulle et ses hôtes à Champs-sur-Marne, 1959-1969: un homme, une ville: la croisée des destins. Paris: Ed. des écrivains 2001. pp 315, il.

225 ROBIN J, The way we lived then [Colyton]. Aldershot: Ashgate 2000. pp x +168 .

226 ADAMS AF, Dover: collected memories of a century. Dover: Triangle Publications 2001. pp viii + 191, il.

227 DEVLIN EN, Speaking volumes: a Dublin childhood. Belfast: Blackstaff P 2000. pp 269.

228 SMITH CJ, Looking back: an autobiographical journey through south Edinburgh and beyond. Edinburgh: Malcolm Cant 2000. pp xi + 116, il.

229 O'NEILL G, My East End: a history of cockney London. London: Viking 1999. pp xxii + 322 , il.

230 GROSS J, A double thread: a childhood in Mile End - and beyond. London: Chatto \& Windus 2001. pp 189.

231 JENKINS S, Primrose Hill remembered. London: Friends of Chalk Farm Library 2001. pp 176, il.

232 PANI M \& ARELLANO GDG, Histoira oral de la ciudad de México: testimonios de sus arquitectos, 1940-1990. Mexico City: Conculta 2000.

233 BIGGATTI G, La citta operosa: Milano nell'Ottocento. Milan: Franco Angeli 2000. 
234 FROMMER M \& FROMMER H, It happened in Manhattan: an oral history of life in the city during the mid-twentieth century. Berkley Books 2001.

235 BONNIN S, Je me souviens du 17e arrondissement. Paris: Parigramme 2001 (réed). pp 119 , il.

236 BRASSEUR B, Je me souviens du 15e arrondissement. Paris: Parigramme 2001 (réed). pp 119, il.

237 COLIN J, Je me souviens des Halles. Paris: Parigramme 2001 (réed). pp 119, il.

238 COURAUD C, Je me souviens du 12e arrondissement. Paris: Parigramme 2001 (réed). il.

239 GOPNIK A, Paris to the moon. London: Vintage 2001. pp $x+338$, il.

240 Journal tenu par un bourgeois de Paris pendant le règne de François 1er. 1. 1515-1524. Clermont-Ferrand: Paleo 2001. pp 192.

241 Journal tenu par un bourgeois de Paris pendant le règne de François 1er. 2. 1524-1536. Clermont-Ferrand: Paleo 2001. pp 192.

242 KRONLUND S, Je me souviens du 9e arrondissement. Paris: Parigramme 2001 (réed). pp 119, il.

243 MORAUX L, Je me souviens du 11e arrondissement. Paris: Parigramme 2001 (réed). pp 119, il.

244 VIALLE C, Je me souviens du 13e arrondissement. Paris: Parigramme 2001 (réed). pp 119, il.

245 SANDWICH LOCAL HISTORY SOCIETY, Sandwich recollected: an oral history, 1914-1950. Sandwich: Sandwich Local History Society 2000. pp 175, il.

Graphic and photographic portrayals

246 SOLES B, Agen: l'entre-deux-guerres. Joué les Tours: A Sutton 2001. pp 128, il.

247 MAINE I \& WHITE J comps, Aldershot. Stroud: Tempus 2000. pp 128, il.

248 CROSS T, Alton. Stroud: Tempus 1999. pp128, il

249 GUIHUR J, Angers traces d'histoire. Joué les Tours: A Sutton 2001. pp 128, il.

250 CLAP S, Avignon. Joué les Tours: A Sutton 2000. pp 128, il.

251 VAUGHAN K, Aylesbury past \& present. Stroud: Budding 1998, pp 125, il.

252 ELLIOTT B, Barnsley: 1890s-1990s. Stroud: Budding Books 2001. pp 126, il.

253 FINCH S, Beckenham and West Wickham. Stroud: Tempus 2000. pp 128, il.

254 CLEMENS J, Bègles. Joué les Tours: A Sutton 2001. pp 128, il.

255 HEATLEY F, Belfast: paintings and stories from the city. Donaghadee, Northern Ireland: Cottage Publications 1998. pp 91, il.

256 GRUDLER C, Belfort et ses quartiers. Joué les Tours: A Sutton 2000. pp 128, il.

257 PRECIGOUT G, Belleville et ses environs. Joué les Tours: A Sutton 2001. pp 128, il.

258 WALER J, Berwick-upon-Tweed. Stroud: Tempus 1999. pp 96, il.

259 TOILLON E, Besançon, ville horlogère. Joué les Tours: A Sutton 2000. pp 128, il.

260 VIALA M, Béziers. Joué les Tours: A Sutton 2001. pp 128, il.

261 RENARD D, Bezons. Joué les Tours: A Sutton 2001. pp 128, il.

262 BEAUFILS M \& BEAUFILS J, Biarritz. Joué les Tours: A Sutton 2001. pp 128, il.

263 HAMPSON M comp, Edgbaston [Birmingham]. Stroud: Tempus 1999. pp 128, il.

264 DUCHEMIN P, Blois. 2. Joué les Tours: A Sutton 2001. pp 128, il.

265 DAVIES M, Around Brecon. Stroud: Tempus 2000. pp 128.

266 SUMNER I \& SUMNER M, Bridlington. Stroud: Budding Books. 2001. pp 126, il.

267 HORLOCK C, Brighton: the century in photographs. Seaford: SB Publications 2000. pp 144 , il.

268 LEE B comp, Central Cardiff the second selection. Stroud: Tempus 1999. pp 128, il.

269 SOUYRI JC, Carmaux. Joué les Tours: A Sutton 2001. pp 128, il.

270 NEWMAN S, Christchurch in old picture postcards. Zaltbommel, Netherlands: European Library 1997. pp 76, il.

271 LECURU JC \& PILOT M, Compiègne. 3. Joué les Tours: A Sutton 2001. pp 128, il.

272 ALZIEU T, Constantine. Joué les Tours: A Sutton 2001. pp 128, il. 
273 DUMONT J \& DUMONT M, Dammarie-les-Lys. Joué les Tours: A Sutton 2001. pp 128, il.

274 DAVID F, Au temps de l'industrie textile. 2. Darnétal. Joué les Tours: A Sutton 2001. pp 128 , il.

275 HAMILTON R, 100 years of Derry. Belfast: Blackstaff P 1999. pp 174, il.

276 DUNNIGAN BL, Frontier metropolis: picturing early Detroit, 1701-1838. Detroit: Wayne State UP 2001.

277 KEARNS KC, Streets broad and narrow: images of vanishing Dublin. Dublin: Gill and Macmillan 2000. pp180, il.

278 BONNET C \& DUCLOS B, Étampes chronique d'un siècle. Joué les Tours: A Sutton 2001. pp 128, il.

279 THOMAS PD, Exeter yesterday \& today. Stroud: Sutton 2000. pp 159, il.

280 ANNAN T, Glasgow Victoriana: classic photographs. Ayr: Fort Publishing 1999. pp 64, il.

281 COFFANO G, Grenoble. 2. Joué les Tours: A Sutton 2001. pp 128, il.

282 MARCHADIER G, Guéret. Joué les Tours: A Sutton 2000. pp 128, il.

283 PILLING JC, Henley-on-Thames past \& present. Stroud: Sutton 2000. pp 127, il.

284 MARCHE J, Héricourt. Joué les Tours: A Sutton 2001. pp 128, il.

285 WILKINSON G, Forgotten Hull 2: a selection of photographs from the 1890s-1930s. Hull: Kingston 2000. pp 119, il.

286 SMITH JE, Hull in the 1950s: a pictorial diary of life in Kingston upon Hull. Beverley: Hutton P 1994. pp 148, il.

287 People E places: a pictorial history. Ipswich: Ipswich and Norwich Co-operative Society 2000. pp 128, il.

288 LE DRET Y \& MAHE JL, La Rochelle et ses quartiers. Joué les Tours: A Sutton 2001. pp 128 , il.

289 BRIAIS B, Une ville de province dans la guerre: Loches en Touraine, 1939-1945. Joué les Tours: A Sutton 2001. pp 128, il.

290 LLOYD S, London. London: Collins \& Brown 1999. pp 159, il.

291 PERRY G ed, London in the sixties. London: Pavilion 2001. pp 128, il.

292 SNOWDON AA-J, London: sight unseen. London: Weidenfeld \& Nicolson 1999. pp 141, il.

293 PAGE AH, Blackheath [London]. Stroud: Sutton 2000. pp 126, il.

294 THOMAS JP, Lourdes. Joué les Tours: A Sutton 2001. pp 128, il.

295 UNIVERSITE INTER-AGE, Melun. Joué les Tours: A Sutton 2001. pp 128, il.

296 MCCKAY K \& SPRINGER G comp, Milford Haven: waterway and town. Stroud: Tempus 1999. pp 128. il.

297 OSWALD G, Molsheim. Joué les Tours: A Sutton 2001. pp 128, il.

298 SAGNARD J, Montbrisson. Joué les Tours: A Sutton 2000. pp 128, il.

299 ARCES A, Montélimar et les Montiliens. Joué les Tours: A Sutton 2001. pp 94, il.

300 COMBEAU JC, Montluçon. Joué les Tours: A Sutton 2001. pp 128, il.

301 TOURET A, Montluçon 1940-1944: la mémoire retrouvée. Nonette: CREER 2001. pp 325.

302 HEPPLEWHITE P comp, Newcastle upon Tyne. Stroud: Tempus 2001. pp 128, il.

303 HUARD R et al, Nîmes. Joué les Tours: A Sutton 2001. pp 128, il.

304 BOUFFARD R \& PEROCHON C, Niort. Joué les Tours: A Sutton 2000. pp 128, il.

305 Memories of Northampton. Elland: True North Books c1999. pp 142, il.

306 WHITWORTH D comp, Nottingham. Stroud: Tempus 2000. pp 96, il.

307 MANTEN H, Nürnberg: eine europäische stadt in mittelalter und neuzeit. Nuremberg: Selbstverlag Des Vereins Für Geschichte Der Stadt Nürnberg 2000.

308 ALZIEU T, Oran. Joué les Tours: A Sutton 2001. pp 128, il.

309 MOUCHEL G, Pauillac. Joué les Tours: A Sutton 2001. pp 128, il.

310 ARISIO J \& ARISIO D, Péronne. Joué les Tours: A Sutton 2001. pp 128, il.

311 REYNAUD G, Pertuis. Joué les Tours: A Sutton 2000. pp 128, il.

312 ANDRES I \& HENSON F, Poole: the second selection. Stroud: Tempus 2000. pp 128, il. 
313 MACLEAY J, Old Portishead. Catrine: Stenlake Publishing 2001. pp 48, il.

314 Romans sur Isère. Joué les Tours: A Sutton 2001. pp 128, il.

315 MUNFORD T, A history of Rotherham. Stroud: Sutton 2000. pp 144, il.

316 TUFFREY P comp, In and around Rotherham. Stroud: Tempus 2000. pp 128, il.

317 QUERCIZE S, Sainte-Adresse. Joué les Tours: A Sutton 2001. pp 128, il.

318 COOK H, Old St Andrews. Catrine: Stenlake Publishing c2001. pp 48, il.

319 DEGORCE F \& BAUDET J, Saint-Claud et son canton. Joué les Tours: A Sutton 2000. pp 128, il.

320 DOUZENEL P, Saint-Denis: 1948-1976. Joué les Tours: A Sutton 2001. pp 128, il.

321 JOLIVET I \& MARTIN E, Saint-Lô court sur un siècle: ballade en clichés. Guilberville: Le cyprès penché 2001. pp 224, il.

322 AUBARBIER JL \& LASFARGUE F, Sarlat: histoire et légendes. Joué les Tours: A Sutton 2001. pp 96, il.

323 MCCUTCHEON B comp, Stirling. Stroud: Tempus 1999. pp 128, il.

324 LONG K, Stoke-on-Trent past \& present. Stroud: Sutton 2000. pp 128, il.

325 Memories of Sunderland, Halifax: True North Books 1998. pp 122, il.

326 ROBERTS D comp, Swansea remembered. Derby: Breedon 2000. pp 208, il.

327 CHAPEU S, Tarbes. Joué les Tours: A Sutton 2001. pp 128, il.

328 ROSSEZ P, Villeneuve-d'Ascq. Joué les Tours: A Sutton 2001. pp 126, il.

329 BEASLEY D comp, Around Wallingford. Stroud: Chalford 1998. pp 128, il.

330 BOTT IM, Wednesbury revisited. Stroud: Sutton 1998. pp 125, il.

\section{Population}

\section{General features of urban populations}

331 ARNAUD JL, La population de Damas à la fin de la période ottomane. ADH 1 (2001)177-208.

332 PARELON G, Gueret à la fin de l'ancien régime: démographie et société. Limoges: PULIM 2000. pp 371, il.

333 WERNER A comp, London bodies: the changing shape of Londoners from prehistoric times to the present day. London: Museum of London 1998. pp 112, il.

\section{Natality and mortality}

334 GAUVREAN D \& GOSSAGE P, Canadian fertility transitions: Quebec and Ontario at the turn of the twentieth century. JFH 262 (2001) 162-88.

335 MONKKONEN E, Estimating the accuracy of historic homicide rates: New York City and Los Angeles. SSH 25 (2001) 53-66.

336 ROHRKASTEN J, Trends of mortality in late medieval London, 1348-1400. NMS XLV (2001) 172-209.

\section{Disease}

337 BOURDAIN A, Typhoid Mary: an urban historical. New York: St Martin's 2001.

338 LEASOR J, The plague and the fire. London: House of Stratus 2001. pp 254.

\section{Migration to, from and between towns}

339 DUBERT I, Attraction urbaine et dynamiques migratoires du service domestique en Galice; 1752-1924. ADH 1 (2001) 155-76.

340 MALONEY TN, Migration and economic opportunity in the 1910s: new evidence on African-American occupation mobility in the north. EEcH 38 (2001) 147-65.

341 OTTERSTROM SM, Trends in national and regional population concentration in the United States from 1790 to 1900: from the frontier to the urban transformation. SSJ 38 (2001) 393-408. 
342 POLASKY J, Transplanting and rooting workers in London and Brussels: a comparative history. JModH 733 (2001) 528-60.

343 ROSE J, Contexts of interpretation: assessing immigrant reception in Richmond, Canada. CG 454 (2001) 474-93.

344 WALL R, The family circumstances of women migrating permanently or temporarily to Sundsvall in the nineteenth century. SEcHR 493 (2001) 46-61.

345 ZALC C, Petits entrepreneurs étrangers en ville. Localisations urbaines, réseaux migratoires et solidarités professionnelles dans la Seine pendant l'entre-deux-guerres. HUr 4 (2001) 67-82.

\section{Family and household structure}

346 TAKAI Y, The family networks and geographic mobility of French Canadian immigrants in early-twentieth-century Lowell, Massachusetts. JFH 263 (2001) 373-94.

\section{Physical structure}

\section{Physical and structural characteristics of towns}

347 CANTWELL AME \& WALL DZ, Unearthing Gotham: the archaeology of New York city. New Haven: Yale UP 2001.

Ancient

348 Buried cities. SW 575 (2000) 13.

349 Ancient cities found in Egyptian Bay. RGSM (2000) 10-14.

350 BLOY D, A craft model for the development of the archaic Athenian Agora. AJA 1052 (2001) 259.

351 COLLINS AL, The Etruscans in the Renaissance: the sacred destiny of Rome and the Historia Virginti Saeculorum of Giles of Viterbo (c.1469-1532). HRef 271 (2001) 107-37.

352 COQUELET C, Organisation et articulation de l'habitat précoce dans les villes du Nord de la Gaule. RN 343 (2001) 9-14.

353 CORLISS W, Ancient structures: remarkable pyramids, forts, towers, stone chambers, cities, complexes. Glenn Arm: The Sourcebook Project 2001.

354 EDWARDS M, Archaeologists unearth clues to ancient cities - long disappeared - that once flourished in the Indus Valley of Pakistan and northwestern India. NG 1976 (2000) 108.

355 FENTRESS E \& ALCOCK SE, Romanization and the city: creations, transformations, and failures: proceedings of a conference held at the American academy in Rome to celebrate the 50th anniversary of the excavations at Cosa, 14-16 May, 1998. Portsmouth: Journal of Roman Archaeology 2000.

356 GOLDMAN A, Gordion under the Flavians: new evidence for romanization and economic development in rural Galatia. AJA 1052 (2001) 272.

357 GORE R, Samson, Goliath, Herod, Alexander, Richard the Lion-Hearted may have walked the streets of Ashkelon, ancient city of the sea. NG 1991 (2001) 66.

358 GURZADYAN VG, Astronomy and the fall of Babylon - how advanced astronomical techniques and data helped determine the year one of the greatest cities in the ancient world fell to invaders. ST 1001 (2000) 40-8.

359 HITCHCOCK L, One cannot export a palace on board a ship: Aegean elements in Cypriot late Bronze Age architecture. AJA 1052 (2001) 305.

360 HOHLFELDER R, Swimming over time: the submerged ruins of Aperlae. AJA 1052 (2001) 299.

361 KABAZI MUNTASSER N, Siting and civic identity: the urban context of the Arch of Septimius Severus in Leptis Magna. AJA 1052 (2001) 271.

362 KAISER A, The urban dialogue: an analysis of the use of space in the Roman city of Empuries, Spain. Oxford: Archaeopress 2000. 
363 KAISER A, The visibility of temples and villas in the Roman urban environment: a case study from Emporiae (Spain). AJA 1052 (2001) 271.

364 MAEIR A \& SOURCE C, Excavating Philistine Gath: have we found Goliath's home town? BArchR (2001) 22-33.

365 MENGEL M \& MURPHY D, A rural Lycian bath house. AJA 1052 (2001) 262.

366 PARLAMA L \& STAMPOLIDIS N eds, Athens: the city beneath the city: antiquities from the metropolitan railway excavations. New York: Harry Abrams 2001.

367 SCHNEIDER RM, Coloured marble: the splendour and power of imperial Rome. Ap (2001) 3-10.

368 STANLEY JD, GODDIDO F \& SCHNEPP G, Geoarchaeology: Nile flooding sank two ancient cities. N 4126844 (2001) 293.

369 WELCH K, The Roman Ampitheater: origin, evolution, canonization. AJA 1052 (2001) 275.

Medieval and early modern (-1800)

370 COWGILL J, Medieval finds from excavations in London. Woodbridge: Boydell P 2000. pp xiii +169 , il.

371 CROWFOOT E, STANILAND K \& PRTICHARD F, Textiles and clothing, c.1150-c.1450: medieval finds from excavations in London. London: Boydell \& Brewer 2001.

372 DUFFY S, Medieval Dublin I: proceedings of the friends of medieval Dublin symposium 2000. Dublin: Four Courts 2001.

373 DUFFY S, Medieval Dublin II: proceedings of the friends of medieval Dublin symposium 2000. Dublin/Portland: Four Courts 2001.

374 GARRIOCH D, Sacred neighborhoods and secular neighborhoods: Milan and Paris in the eighteenth century. JUH 274 (2001) 405-19.

375 HANAWALT B \& KOBIALKA M, Medieval practices of space. Minneapolis: U of Minnesota P 2000.

376 HARRINGTON S, Digging in the City of Light - irrepressible and irreverent, Michel Fleury has spent a lifetime excavating and preserving medieval Paris. Arch 2 (2000) $52-7$.

377 LENOIR L, A la découverte des anciennes fortifications de Calais. Cambrai : Nord Patrimoine 2001.

378 MCCORMICK A, Nottingham's underground maltings and other medieval caves: architecture and dating. ThS 105 (2001) 73-99.

379 MEDICK H, Historical event and contemporary experience: the capture and destruction of Magdeburg in 1631. HWJ 52 (2001) 23-48.

380 RYNNE C, The industrial archaeology of Cork city and its environs. Dublin: Stationery Office 1999. pp xiii + 325, il.

381 SCHRYVER JG, Medieval settlement at the villa of Horace. AJA 1052 (2001) 306.

382 SCHUMANN D ed, Bauforschung und archaologie: stadt - und siedlungsentwicklung im spiegelder baustrukturen. Berlin: Lukas 2000.

383 SMIRNOVA L, Utilization of rare bone materials in medieval Novgorod. BARI 937 suppl (2001) 9-18.

384 SPURGEON CJ, The medieval town defences of Glamorgan. SC XXXV (2001) 161-212.

385 TRACY JD ed, City walls: the urban enceinte in global perspective. Cambridge: Cambridge UP 2000.

Modern (1800-)

386 HICKMAN CM, Building for science: Carnegie institution of Washington's geophysical laboratory. WH 13 (2001) 32-51, 92-3.

387 JO S, Genesis and evolution: morphogenesis of spatial configuration in Atlanta. JUH 271 (2000) 24-49.

388 KONADU-AGYEMANG K, Structural adjustment programs and housing affordability in Accra, Ghana. CG 454 (2001) 528-44. 
389 LESLIE SW, Regional disadvantage: replicating silicon valley in New York's capital region. TC (2001) 236-64.

390 MENANTEAU L \& PERERA SAN MARTIN N, Quand la ville se mirait dans l'eau: quais de Loire à Nantes. Indre: Ponctuation 2000. pp 102, il.

391 VANDERBILT T, Survival city: adventures among the ruins of atomic America. New York: Princeton Architectural P 2002.

\section{Physical and structural characteristics of areas within towns}

392 FEIRSTEIN S, Naming New York: Manhattan places and how they got their names. New York: New York UP 2001

393 GRAY RD, Cambridge street-names: their origins and associations. Cambridge: Cambridge UP 2000.

394 JONES AE, St Mary's Street, St Neots, Cambridgeshire, archaeological investigations 1994-5. Birmingham: Birmingham University Field Archaeology Unit 2000. pp vi + 35, il.

395 ROBINSON C, Union Street. Plymouth: Pen \& Ink 2000. pp iv + 123, il.

The central business district

396 FOGELSON RM, Downtown: its rise and fall, 1880-1950. New Haven: Yale UP 2001.

Industrial areas

397 MONTEL N, Mutations spatiales, stratégies professionnelles et solidarités familiales à Paris au XIXe siècle. Le rôle des raffineurs de sucre villetois dans la formation d'un espace industriel. HUr 4 (2001) 47-66.

Slums

398 MAYNE AJC \& MURRAY T, The archaeology of urban landscapes: explorations in slumming. Cambridge: Cambridge UP 2001.

Suburbs

399 SHIRE A ed, Belsize 2000: a living suburb. London: Belsize Conservation Area Advisory Committee c2000. pp 136, il.

Open space

400 BACHRACH JS, The city in a garden: a photographic history of Chicago's parks. Centre for American Places 2001.

401 HERWITZ E, Trees at risk: reclaiming an urban forest, a case history of Worcester. Worcester, Mass: Chandler House 2001.

402 LONGSTAFFE-GOWAN T, The London town garden, 1740-1840. New Haven: Yale UP 2001.

403 SCOTT R, A breath of fresh air: the story of Belfast's Parks. Belfast: Blackstaff P 2000.

404 TITTLE D, A walk in the park: greater Cleveland's new and reclaimed green spaces. Columbus: Ohio State UP 2001.

\section{Industrial and building sites, building development}

405 ANDROS HS, Buildings and landmarks of Old Boston: a guide to the colonial and provincial, federal, and Greek revival periods. Hanover: UP of New England 2001.

406 BUNDOCK M, Herne Bay clock tower: a descriptive history. Herne Bay: Pierhead 2000. pp 28, il.

407 CARLEY JP ed, Glastonbury abbey and the Arthurian tradition. Woodbridge: DS Brewer 2001. pp xii +646 , il.

408 ELLIS P ed, The Roman baths and macellum at Wroxeter: excavations by Graham Webster 1955-85. London: London Heritage 2000. pp xv + 394, il. 
409 KAUFFMAN JE, KAUFFMAN HW \& JURGA R, The medieval fortress: castles, forts and walled cities of the middle ages. London: Greenhill Books 2001.

410 KING R, Brunelleschi's dome: the story of the great cathedral in Florence. London: Pimlico 2001.

411 LE GOIC P, Brest en reconstruction: antimémoires d'une ville. Rennes: UP Rennes 2001. pp 356, il.

412 LEPAGE J-D, Castles and fortified cities of medieval Europe: an illustrated history. London: McFarland 2001

413 PAVITT J, Prague, the buildings of Europe. Manchester: Manchester UP 2000.

414 RICHMOND C \& SCARFF E, St Georges chapel, Windsor, in the later middle ages. Leeds: Maney Publishing 2001. pp viii +214 , il.

415 SEYMOUR D, The exchequer cartulary of Torre Abbey. Torquay: Friends of Torre Abbey 2001. pp 571.

416 STEANE K \& DARLING MJ et al, The archaeology of Wigford and the Brayford pool. Oxford: Oxbow 2001. pp viii + 360, il.

417 WILLEY A, York Minster. London: Scala 1998. pp 96, il.

Land ownership

418 CHAUVARD JF, Investir au plus proche. Le comportement immobilier de commerçants et d'artisans dans la Venise du XVIIe siècle. HUr 4 (2001) 9-26.

419 STOBART J \& OWENS A eds, Urban fortunes: property and inheritance in the town, 1700-1900. Aldershot: Ashgate 2000.

Architecture

420 AGOSTINO M ed, La cathédrale Saint-André, reflet de neuf siècles d'histoire et de vies bordelaises. Pessac: UP de Bordeaux 2001. pp 173, il.

421 BACHA M, Le 14e arrondissement: itinéraires d'histoire et d'architecture. Paris: Action artistique de la ville de Paris 2000. pp 144, il.

422 BELMONT J, Lire l'architecture des bâtiments parisiens: une promenade le long de la Seine. Paris: Parigramme 2001. pp 160.

423 BLAU E \& PLATZER M, eds, Shaping the great city: modern architecture in central Europe, 1890-1937. London: Prestel 2000.

424 BORDEN I, The unknown city: contesting architecture and social space: a strangely familiar project. Cambridge, Mass: MIT P 2001.

425 CENTORAME B, Le 9e arrondissement: itinéraires d'histoire et d'architecture. Paris: Action artistique de la ville de Paris 2000. pp 144, il.

426 CHICHE V, Le 2e arrondissement: itinéraires d'histoire et d'architecture. Paris: Action artistique de la ville de Paris 2000. pp 144, il.

427 COLVIN H, Essays in English architectural history. New Haven: Yale UP 1999.

428 CROIZIER L, Le grand théatre de Bordeaux. Bordeaux: Confluences 2001. pp 40, il.

429 DAUFRESNE JC, Fêtes à Paris au XXe siècle: architectures éphémères de 1919 à 1989. Liège: Mardaga 2001. pp 287, il.

430 ERLANDE BRANDEBURG A \& ERLANDE BRANDENBURG B, Saint-Germain des Près. Paris: Gisserot 2001. pp 32, il.

431 EXPOSITION. MANTES-LA-JOLIE, MUSÉE DE L'HÔTEL-DIEU, Mantes médiévale: la collégiale au cœur de la ville: exposition, Mantes-la-Jolie, Musée de l'Hôtel-dieu. Paris: Somogy 2001. pp 192, il.

432 FESSY G, Lyon, vingt-cinq siècles de confluences. Paris: Imprimeur Nationale 2001. pp 258, il.

433 GENUITE M, Le 19e arrondissement: itinéraires d'histoire et d'architecture. Paris: Action artistique de la ville de Paris 2000. pp 144, il.

434 GEORGOPOULOU M, Venice's Mediterranean colonies: architecture and urbanism. Cambridge: Cambridge UP 2001. 
435 GISBERTZ O, Bruno Taut and Johannes Goderitz in Magdeburg: archicktur and stadtebau in der Weimarer Republik. Berlin: Gebr. Mann 2000.

436 GRANT KS, The rainbow city: celebrating light, color, and architecture at the pan-American exposition, Buffalo, 1901. Buffalo: Canisius College P 2001.

437 HENRY-GOBET A, Le 10e arrondissement: itinéraires d'histoire et d'architecture. Paris: Action artistique de la ville de Paris 2000. pp 144, il.

438 IBELINGS H ed, The artificial landscape: contemporary architecture in the Netherlands. Rotterdam: NAI Publishers 2000.

439 JEREMIAH D, Architecture, design and the family in twentieth century Britain, 1900-1970. Manchester: Manchester UP 2000.

440 LAGRANGE H, Le 15e arrondissement: itinéraires d'histoire et d'architecture. Paris: Action artistique de la ville de Paris 2000. pp 144, il.

441 LHOR E, Le 1er arrondissement: itinéraires d'histoire et d'architecture. Paris: Action artistique de la ville de Paris 2000. pp 144, il.

442 MARECHAL S, Le 12e arrondissement: itinéraires d'histoire et d'architecture. Paris: Action artistique de la ville de Paris 2000. pp 144, il.

443 MINNE E, Le 8e arrondissement: itinéraires d'histoire et d'architecture. Paris: Action artistique de la ville de Paris 2000. pp 144, il.

444 MONTCLOS B, Civilisation de Saint-Pétersbourg. Paris: Mengès 2001. pp 278, il.

445 PACCIANI R, Renaissance architecture in Florence: the fifteenth century. Rizzoli International 2001

446 PANOUILle JP, La cité de Carcassonne: Aude. Paris: Ed. du Patrimoine 2001. pp 64, il.

447 PARKINSON-BAILEY JJ, Manchester, an architectural history. Manchester: Manchester UP 2000.

448 PLUM G, Villas balnéaires du second Empire: Trouville, Deauville et Côte fleurie: exposition Musée de la Villa Montebello, Trouville, 14 juillet-23 septembre 2001. Cabourg: Cahier du temps 2001. pp 119, il.

449 PUPPI L, Les pierres de Venise. Paris: F Hazan 2001. pp 192, il.

450 QUEREEL P, Un siècle d'architectures à Rouen. Paris: Laffont 2001. pp 128, il.

451 ROLLENHAGEN-TILLY L, Le 6e arrondissement: itinéraires d'histoire et d'architecture. Paris: Action artistique de la ville de Paris 2000. pp 144, il.

452 SALAS CG \& ROTH MS eds, Looking for Los Angeles: architecture, film, photography, and the urban landscape. Los Angeles: Getty Research Institute 2001.

453 SCHEER T, KEIHUES JP \& KAHLFELDT P, eds, Architecture of the city: Berlin 1900-2000. Berlin: Nicolai 2000.

454 STEINER M, Parables of stone and steel: architectural images of progress and nostalgia at the Columbian Exposition and Disneyland. AMS 42 (2001) 39-67.

455 STOREY G, Regionaries-type insulae I: architectural/residential units at Ostia. AJA 1053 (2001) 389.

456 TEXIER S, Le 13e arrondissement: itinéraires d'histoire et d'architecture. Paris: Action artistique de la ville de Paris 2000. pp 144, il.

457 ZIEGLER C, Les trésors de Tanis: capitale oubliée des pharaons de l'an mille. Paris: Picard 2001. pp 96, il.

\section{Housing}

458 BOVE B, La demeure bourgeoise à Paris au XIVe siècle: bel hôtel ou 'grant meson'? HUr 3 (2001) 67-82.

459 JEFFERY F, Housing in Linton, Cambridgeshire in the 19th and 20th centuries. Linton: Linton and District Historical Society 2001. pp 126, il.

460 NEVETT L, House and society in the ancient Greek world. Cambridge: Cambridge UP 2001.

461 RILLING DJ, Making houses, crafting capitalism: builders in Philadelphia, 1790-1850. Philadelphia: U of Pennsylvania P 2000. 
462 VALE LJ, From the puritans to the projects: public housing and public neighbourhoods. Cambridge, Mass: Harvard UP 2000.

House building

463 CARR K, Roman, Visigothic and Islamic houses: changes in the construction of Iberian domestic space over time. AJA (2001) 306.

464 COURTWRIGHT J, Want to build a miracle city? War housing in Wichita. KH 23 (2000-2001) 218-39.

Building industry and methods

465 FARAGHER JM, Bungalow and ranch house: the architectural backwash of California. WHQ 32 (2001) 149-74.

466 HUNT DB, What went wrong with public housing in Chicago? A history of the Robert Taylor homes. JISHS 93 (2001) 96-123.

467 KEARNS K comp, Dublin tenement life: an oral history. London: Penguin Books 2000.

468 MARCUS S, Haussmannization as anti-modernity: the apartment house in Parisian urban discourse, 1850-1880. JUH 275 (2001) 723-45.

Housing conditions

469 CUSTERS G, Inner city rental housing in Lima: a portrayal and an explanation. C 184 (2001) 249-58.

470 DELAVAL E, Forme d'habitat collectif à Lyon et Vienne en milieu artisanal et commercial. RN 343 (2001) 35-50.

471 DURHART F, Habiter et consommer à Bayonne au XVIIIe siècle: éléments d'une culture matérielle urbaine. Paris: L'Harmattan 2001. pp 286.

472 KELLETT P, Voices from the barrio: oral testimony and informal housing processes. TWPR 222 (2000) 189-205.

473 MORRIS S, Market solutions for social problems: working-class housing in nineteenth-century London. EcHR XIV 3 (2001) 525-45.

\section{Environmental conditions}

474 BOURNE PJ, London's greatest trees. JLS 441 (2001) 14-16.

475 BURNES B, High \& rising: the 1951 Kansas city flood. Kansas City: Star Books 2001.

476 HERMARY A \& TREZINY H, Marseille, trames et paysages urbains de Gyptis au roi René: actes du colloque international, Aix-en-Provence-Marseille, 4-5 juin 1999. Aix-en-Provence: Edisud 2001. pp 448, il.

477 HERWITZ E, Trees at risk: reclaiming an urban forest, a case history of Worcester, Massachusetts. Worcester, Mass: Chandler House 2001.

478 MILLER C, On the border: an environmental history of San Antonio. Pittsburgh: U of Pittsburg P 2001.

\section{Social structure}

\section{Social structure and characteristics of towns}

479 MAHONEY O, Douglas/Grand boulevard: a Chicago neighbourhood. Charleston: Arcadia 2001.

480 PORTER R, London: a social history. London: Penguin Books 2000. pp xvii + 541, il.

Ancient

481 DYSON S, Community and society in Roman Italy. Baltimore: Johns Hopkins UP 2001.

482 POLLARD N, Soldiers, cities and civilians in Roman Syria. Ann Arbor: U of Michigan P 2000.

483 VEYNE P, La société romaine. Paris: Seuil 2001 (réed). pp 368. 
Medieval and early modern (-1800)

484 ALIQUOT H, Avignon au temps des papes. Veurey: le Dauphiné 2000. pp 52, il.

485 BRUNI L, History of the Florentine people. Vol. 1, books 1-4. Cambridge/London: Harvard UP 2001.

486 FLAVELL JM \& HAY G, Capture-recapture methods and colonial Americans in London. JInH XXXII 1 (2001) 37-53.

487 FRENCH K, The people of the parish: community life in late medieval English diocese. Philadelphia: U of Pennsylvania P 2001.

488 GRIFFITHS P \& JENNER MSR eds, Londonopolis, c. 1500-c1750: essays in the cultural and social history of early modern London. Manchester: Manchester UP 2000. pp xi +284 , il.

489 HALL D \& UNWIN C, Burgess, merchant and priest: the medieval Scottish town. Edinburgh: Birlinn 2001.

490 KINDA A, The concept of 'townships' in Britain and the British colonies in the seventeenth and eighteenth centuries. JHG 272 (2001) 137-52.

491 KLUSAKOVA L, Between reality and stereotype: town views of the Balkans. UH 283 (2001) 358-77.

492 KOSCHNIK A, The democratic societies of Philadelphia and the limits of the American public sphere, circa 1793-1795. WMQ LVIII 3 (2001) 615-36.

493 LAUGHTON J, JONES E \& DYER C, The urban hierarchy in the later middle ages: a study of the East Midlands. UH 283 (2001) 331-57.

494 LILLEY KD, Urban life in the middle ages, 1000-1450. New York: Palgrave 2001.

495 LYONS CA, Single in the Quaker city. RAmH 291 (2001) 15-22.

496 MACCORMACK S, History, historical record and ceremonial action: Incas and Spaniards in Cuzco. CSSH 432 (2001) 329-63.

497 MCINTOSH T, Urban demographic stagnation in early modern Germany: a simulation. JInH XXXI 4 (2001) 581-612.

498 MILLER PN, Friendship and conversation in seventeenth-century Venice. JModH 731 (2001) 1-31.

499 SHEPARD A \& WITHINGTON P, Communities in early modern England: networks, place, rhetoric. Manchester: Manchester UP 2000. pp xii + 276.

500 TITTLER R, Reconsidering the 'English urban renaissance': cities, culture and society after the Great Fire of London. JBS 403 (2001) 419-30.

Modern (1800-)

501 ARNOLD D, Re-presenting the metropolis: architecture, urban experience and social life in London, 1800-1840. Aldershot: Ashgate 2000.

502 BATES JH, Adjusting to change: privilege and place in post-Soviet central Moscow. CG 452 (2001) 237-51.

503 CHA-JUA SK, America's first black town: Brooklyn, Illinois, 1830-1915. Urbana: U of Illinois P 2000.

504 COBURN A, No second Eden: social conditions in Harpenden in the late 1850s. HP 51 (2001) 17-21.

505 DEBUCHY V, La vie à Paris sous la commune. Paris: Christian 2001. pp 300.

506 FAURE A, Un peuple dans sa ville ou le cours d'une longue recherche. Gen 42 (2001) 92-105.

507 JONES KG \& DOUCET MJ, The big box, the flagship and beyond: impacts and trends in the Greater Toronto area. CG 454 (2001) 494-512.

508 LISTER RC, Friendly societies in the parish of Halifax, 1741-1834. HAS 9 (2001) 63-78.

509 MUNCY R, Disconnecting: social and civic life in America since 1965. RAmH 291 (2001) 141-49.

510 SAMPLE B, A truly midwestern city: Indianapolis on the eve of the great depression. InMH 97 (2001) 129-47. 
511 SCHIRMER SL, A city divided: the racial landscape of Kansas city, 1900-1960. Columbia: $\mathrm{U}$ of Missouri P 2002.

512 SELIGMAN AI, 'Apologies to Dracula, Werewolf, and Frankenstein': white homeowners and blockbusters in postwar Chicago. JISHS 93 (2001) 70-95.

513 THORPE D, Aylesbury and High Wycombe in 1881: an essay in census statistics. $R B u$ 41 (2001) 217-31.

514 WARNER C, Freret's century: growth, identity and loss in a New Orleans neighborhood. LaH 42 (2001) 323-58.

515 WASSERSTROM JN, New approaches to old Shanghai. JInH XXXII 2 (2001) 263-79.

516 WERNER RD, The New South creed and the limits of radicalism: Augusta, Georgia, before the 1890s. JSH LXVII 3 (2001) 573-600.

517 ZHAO Z, Registered household and micro-social structure in China: residential patterns in three settlements in Beijing area. JFH 261 (2001) 39-65.

Twilight areas

518 BROWN G, Listening to queer maps of the city: gay men's narratives of pleasure and danger in London's East End. OH 291 (2001) 48-61.

519 VAN SITTERT L, 'To live this poor life': remembering the Hottentots Huisie squatter fishery, Cape Town c.1934-c.1965. SH 261 (2001) 1-21.

Slums

520 ANBINDER T, Five points: the 19th century network city neighbourhood that invented tap dance, stole elections, and became the world's most notorious slum. New York: Free P 2001.

Working-class areas

521 GOLDBERG A, World's end for Sir Oswald: portraits of working-class life in pre-war London. Lewes: Book Guild 1999. pp 106, il.

Suburbs

522 BLOOM ND, Suburban alchemy: 1960s new towns and the transformation of the American dream. Columbus: Ohio State UP 2001.

523 FERGUSON CC, River Oaks: 1920s suburban planning and development in Houston. SWHQ 104 (2000) 191-230.

524 FROST L, The history of American cities and suburbs: an outsider's view. JUH 273 (2001) 362-76.

525 GARDNER T, The slow wave: the changing residential status of cities and suburbs in the United States, 1850-1940. JUH 273 (2001) 293-312.

526 GRIFFEN C, The new world working-class suburb revisited: residential differentiation in Caversham, New Zealand. JUH 274 (2001) 420-44.

527 HARRIS R \& LEWIS R, The geography of North American cities and suburbs, 1900-1950. JUH 273 (2001) 262-92.

528 KEATING AD, Cities, suburbs and their regions. JUH 275 (2001) 650-7.

529 LEWIS RD, A city transformed: manufacturing districts and suburban growth in Montreal, 1850-1929. JHG 271 (2001) 20-35.

530 LEWIS RD, Industrial suburbanization of Canadian and American cities, 1850-1950. JHG 271 (2001) 1-2.

531 MARTINSON T, American dreamscape: the pursuit of happiness in post war suburbia. New York: Carroll \& Graf 2001.

532 MATTINGLY PH, Suburban landscapes: culture and politics in a New York metropolitan community. Baltimore: Johns Hopkins UP 2001.

533 MULLER EK, Industrial suburbs and the growth of metropolitan Pittsburgh, 1870-1920. JHG 271 (2001) 58-73.

534 OLIVER JE, Democracy in suburbia. Princeton: Princeton UP 2001. 
535 SCHRAG ZM, Mapping metro, 1955-1968: urban, suburban, and metropolitan alternatives. WH 13 (2001) 4-23, 90-2.

536 SELF R, Writing landscapes of class, power and racial division: the problem of (sub)urban space and place in postwar America. JUH 272 (2001) 237-50.

537 SIES MC, Moving beyond scholarly orthodoxies in North American suburban history. JUH 273 (2001) 355-61.

538 SIES MC, North American suburbs, 1880-1950: cultural and social reconsiderations. JUH 273 (2001) 313-46.

539 WALKER R, Industry builds the city: the suburbanization of manufacturing in the San Francisco Bay area, 1850-1940. JHG 271 (2001) 36-57.

\section{Social organization, clubs and societies}

540 HUGHES-HALLETT P, The immortal dinner: a famous evening of genius and laughter in literary London, 1817. London: Viking 2000. pp xxvi +336, il.

\section{Class structure}

541 BECKERT S, Capital and power: New York city and the rise of the American bourgeoisie. Cambridge: Cambridge UP 2001.

Occupational structure

542 BAO X, Holding up more than half the sky: Chinese women garment workers in New York city, 1948-1992. Urbana: U of Illinois P 2001.

543 FÜSSEL S \& VOGEL K, Deutsche handwerker, künstler und gelehrte im rom der renaissance: akten des interdisziplinären symposions vom 27. und 28. Mai 1999 im Deutschen Historischen Institute in rom. Wiebaden: Harrassowitz Verlag 2001.

544 IBN BUTLAN, Séville musulmane au début du XIIe siècle: le traité d'Ibn Abdun sur la vie urbaine et les corps de métiers. Paris: Maisonneuve et Larose 2002 (réed). pp 192.

545 WHALEN CT, From Puerto Rico to Philadelphia: Puerto Rican workers and post war economies. Philadelphia: Temple UP 2001.

Class complsition and interaction

546 GUNN S, The public culture of the Victorian middle class, ritual and authority in the English industrial city, 1840-1914. Manchester: Manchester UP 2001.

547 KIDD A \& NICHOLLS D eds, Gender, civic culture and consumerism: middle class identity in Britain 1800-1940. Manchester: Manchester UP 1999.

548 RUGGIN F-J, The urban gentry in England, 1660-1780, a French approach. HR 74185 (2001) 249-70.

549 WIESE A, Stubborn diversity: a commentary on middle-class influence in workingclass suburbs, 1900-1940. JUH 273 (2001) 347-54.

Social and class attitudes

550 ANDREW DT \& MCGOWEN R, The Perreaus and Mrs Rudd: forgery and betrayal in eighteenth-century London. Berkeley: U of California P 2001.

551 AUBERT G, La noblesse et la ville au XVIIIe siècle. Réflexions à partir du cas rennais. HUr 4 (2001) 127-49

552 BRAND H, Les élites de Leyde et leurs familles à la fin du moyen-âge. Morphologie, rapports et strutures. RH 619 (2001) 603-38.

553 EALHAM C, Class and the city: spatial memories of pleasure and danger in Barcelona 1914-23. OH 291 (2001) 33-49.

554 GOOD JA, 'A world historical idea': the St Louis Hegelians and the civil war. JAS 34 (2000) 447-64.

555 JACOBSON SH, Droit et politique dans l'Espagne du XIXe siècle: les avocats barcelonais et la spécificité du libéralisme catalan. Gen 45 (2001) 4-26. 
556 LENEMAN L \& MITCHISON R, Sin in the city: sexuality and social control in urban Scotland 1160-1780. Edinburgh: Scottish Cultural P 1998. pp vii + 163, il.

557 SALAMAGNE A, Les garnisons des villes et châteaux dans le Nord de la France aux XIVe et XVe siècles. RN 342 (2001) 707-30.

558 TURNER J, Libertines and radicals in early modern London: sexuality, politics and literary culture, 1630-1685. Cambridge: Cambridge UP 2001.

Protests and disorders

559 BARRANTES MA, De la pasividad a la violencia: las manifestaciones de protesta de los esclavos limefios a fines del siglo XVIII. HyC 24 (2001) 15-26.

560 BAUERLEIN M, Negrophobia: a race riot in Atlanta, 1906. San Francisco: Encounter Books 2001.

561 BIDOUZE R, 72 jours qui changèrent la cité. Pantin: Temps des cerises 2001. pp 220 [1st pub. 1870]

562 BROPHY AL, Reconstructing the dreamland: the Tulsa race riot of 1921, race, reparations and reconciliation. New York: Oxford UP 2002.

563 BROWN FB, NAACP sponsored sit-ins by Howard University students in Washington, DC 1943-1944. JNH 85 (2000) 274-86.

564 CHENEY JC, La colère du peuple à Byzance (Xe-XIIe siècles). HUr 3 (2001) 25-38.

565 EINAUDI JL, La bataille de Paris: 17 octobre 1961. Paris: Seuil 2001. pp 432.

566 GAL P, Peurs urbaines et engagements politico-religieux au XVIe siècle: l'exemple de la Ligue grenobloise. HES 1 (2001) 3-22.

567 HOEBER FW, Drama in the courtroom: theater in the streets: Philadelphia's Irish riot of 1831. PenMHB 125 (2001) 191-32.

568 HOLLANDSWORTH JG, An absolute massacre: the New Orleans race riot of July 30, 1866. Baton Rouge: Louisiana State UP 2001.

569 LAMB G, Aylesbury in the civil war. RBu 41 (2001) 183-89.

570 MEADE T, Holding the junta accountable: Chile's 'Sitios de Memoria' and the history of torture, disappearance and death. RHR 79 (2001) 123-39.

571 MINCHIN TJ, Permanent replacements and the breakdown of the 'social accord' in Calera, Alabama, 1974-1999. LH 424 (2001) 371-96.

572 MORRIS JM, A chink in the armor: the black-led struggle for school desegregation in Arlington, Virginia and the end of massive resistance. JPH 13 (2001) 329-66.

573 MUSKETT P, The Maidstone prison mutiny of 1765: aspects of eighteenth-century law enforcement. SouH 23 (2001) 30-51.

574 NOËL B, Dictionnaire de la Commune. Paris: Mémoire du livre 2001 (3rd ed). pp 648.

575 OATES J, Halifax and the Jacobite revolution of 1745. HAS 9 (2001) 100-6.

576 SMITH P, Squalor and rough justice in Watford. Hist 69 (2001) 22-6.

577 STRADLING D, Dirty work and clean air: locomotive firemen environmental activists and stories of conflict. JUH 281 (2001) 35-54.

578 TAGER J, Boston riots: three centuries of social violence. Boston: Northeastern UP 2000.

579 WOLFF L, Dynastic conservatism and poetic violence in fin-de-siècle Cracow: the Habsburg matrix of Polish modernism. AHR 1063 (2001) 735-64.

580 WOOD A, Revolution in the street: women, workers and urban protest in Veracruz, 1870-1927. Wilmington, Del: Scholarly Resources 2001.

\section{Social life}

581 DAVIS B, Home fires burning: food, politics, and everyday life in World War I. Berlin: U of North Carolina 2000.

582 PERRY G ed, Paris in the sixties. London: Pavilion 2001. pp 127, il. 
Social life, customs and traditions

583 CLIFFORD DL, Can the uniform make the citizen? Paris 1789-1791. ECS 34 (2000-2001) 363-82.

584 HARDY C, Prodigal sons, trap doors and painted women: some reflections on urban folklore, life stories and aural history. OH 291 (2001) 98-105.

585 LAVEN M, Sex and celibacy in early modern Venice. JH 444 (2001) 865-88.

586 METAYER C, Normes graphiques et pratiques de l'écriture. Maîtres écrivains et écrivains publics à Paris aux XVIIe et XVIIIe siècles. AHSS 4-5 (2001) 881-902.

587 PICARD L, Dr Johnson's London: life in London, 1740-1770. London: Weidenfeld \& Nicolson 2000. pp xxi +362 , il.

588 TADDEI I, L'encadrement des jeunes à Florence au XVe siècle. HUr 3 (2001) 119-32.

589 TLUSTY BA, Bacchus and civic order: the culture of drink in early modern Germany. Charlottesville: UP of Virginia 2001.

590 VAN DAMME S, Sociabilité et culture urbaines: le rôle du collège de la Trinité à Lyon (1640-1730). HE 90 (2001) 79-100.

591 WAKEMAN R, Paris and London in the nineteenth century. JUH 272 (2001) 200-5.

592 WALLER M, 1700: scenes from London life. London: Hodder and Stoughton 2000. pp vii +388, il.

\section{Religion}

593 BACKUS I, Reformation readings of the apocalypse: Geneva, Zurich, and Wittenberg. Oxford: Oxford UP 2000.

594 BALMER R \& RANDALL C, 'Her duty to Canada': Henriette Feller and French protestantism in Québec. ChH 701 (2001) 49-72.

595 BIGET J-L \& BOUCHERON P, Religion et société urbaine au moyen âge: études offertes à Jean-Louis Biget par ses anciens élèves. Paris: Publications de la Sorbonne 2000.

596 BONZON A, Paroisse rêvée, paroisse vécue: le point de vue de curés citadins au temps de la réforme catholique. L'exemple de Beauvais. RN 340 (2001) 319-40.

597 CAMINO M, Practising places: Saint Teresa, Lazarillo and the early modern city. Amsterdam/Atlanta: Rodopi 2001.

598 CAMPBELL TW, The sisters of the church and the Anglican diocese of Sydney, 1892-1893: a controversy. JRS 252 (2001) 188-206.

599 CARTER J, The religious life of ancient Rome: a study in the development of religious consciousness from the foundation of the city until the death of Gregory the Great. UP of Pacific 2001.

600 CELENZA C \& NESI G, Piety and Pythagoras in renaissance Florence: the symbolum nesianum. Leiden/Boston: Brill 2001.

601 COLETTE S, Les religieuses de la Visitation Sainte-Marie de la ville d'Amiens aux XVIIe et XVIIIe siècles. RN 341 (2001) 519-40.

602 COMERFORD K, Ordaining the Catholic reformation: priests and seminary pedagogy in Fiesole, 1575-1675. Florence: Olschki 2001.

603 CRAIG J, Reformation, politics, and polemics: the growth of Protestantism in East Anglia market towns, 1500-1610. Aldershot: Ashgate 2001.

604 DUMONS B, Villes et ouvriers. Des territoires pour l'histoire sociale et religieuse de la France contemporaine. RHEF 218 (2001) 111-32.

605 DYE R, Catholic protectionism or Irish nationalism? Religion and politics in Liverpool, 1829-1845. JBS 403 (2001) 357-390.

606 EDGERTON S, Theaters of conversion: religious architecture and Indian artisans in colonial Mexico. Albuquerque: U of New Mexico P 2001.

607 GALLT Y, 1143-1202? À propos d'une bulle d'indulgence pour la construction de la cathédrale d'Évreux. AdN 2 (2001) 99-110.

608 GENDZEL G, Pioneers and padres: competing mythologies in Northern and Southern California, 1850-1930. WHQ 32 (2001) 55-80. 
609 GIGGIE JM \& WINSTON DH, Faith in the market: religion and the rise of urban commercial culture. New Brunswick: Rutgers UP 2002.

610 GUNNARSDOTTIR E, The convent of Santa Clara, the elite and social change in eighteenth century Queretero. JLACS 332 (2001) 257-90.

611 HEIJMANS M, Cesaire d'Arles, un évêque et sa ville. RHEF 218 (2001) 5-26.

612 HUTCHINSON RJ, When in Rome: an unauthorised guide to the Vatican. London: HarperCollins 1999. pp 289.

613 JULIEN D, Le couvent des Carmes de Limoges. Limoges: Culture et patrimoine de Limousin 2001. pp 84, il.

614 KAY R, Romanus and Rouen: a papal legate's tainted visitation in 1227. AdN 2 (2001) $111-20$.

615 LAUX S, Reformationsversuche in Kurkö (1542-1548): Fallstudien zu einer strukturgeschichte landstädtischer reformation (Neuss, Kempen, Andernach, Linz). Münster: Aschendorff 2001.

616 LEDUC C, Géographie paroissiale en milieu urbain. L'exemple cambrésien à l'époque moderne. RN 340 (2001) 359-80.

617 MALDAVKY A, Itinéraires des nouveaux chrétiens à Lima. Le proces de Manuel Bautista Pérez et la 'grande complicité' (1635-1639). Ca 74 (2000) 41-59.

618 MALINA BJ, The new Jerusalem in the revelation of John: the city as symbol of life with god. Collegeville: Liturgical P 2000.

619 NUNEZ SEIXAS XM, Redes sociales y asociacionismo: las 'parroquias' gallegas de Buenos Aires (1904-1936). EIAL 111 (2000) 23-44.

620 Ortmann V, Reformation und einheit der kirche: Martin Bucers einigungsbemühungen bei den religionsgesprächen in Leipzig, Hagenau, Worms und Regensburg 1539-1541. Mainz: Von Zabern 2001.

621 PAPROTH D, Henry Varley and the Melbourne evangelicals. JRS 252 (2001) 173-87.

622 QUINN JA, 'Her sons and daughters are ever on the altar': Fisk University and missionaries to Africa, 1866-1937. THQ 60 (2001) 16-37.

623 RIMMINGTON GT, Thomas Robinson: evangelical clergyman in Leicester, 1774-1813. TLAHS 75 (2001) 105-17.

624 RODGERS SB, La comunidad judía alepina en Buenos Aires: de la ortodoxia religiosa a la apartura y de la apertura a la ortodoxia religiosa. EIAL 111 (2000) 65-88.

625 VALONE DAVID A, Hugh James Rose's Anglican critique of Cambridge: science, antirationalism, and Coleridgean idealism in late Georgian England. AlB 332 (2001) 218-42.

626 WALSH AH ed, Can charitable choice work?: covering religion's impact on urban affairs and social services. Hartford: Leonard E Greenberg Center for the Study of Religion in Public Life 2001.

627 WARD MA, A mission for justice: the history of the first African American Catholic church in Newark, New Jersey. Knoxville: U of Tennessee P 2002.

628 WATT J, Choosing death: suicide and Calvinism in early modern Geneva. Kirksville: Truman State UP 2001.

629 WILSON B, The spirit of the motor city: three hundred years of religious history in Detroit. MHR 27 (2001) 21-56.

630 WOLFART J, Religion, government and political culture in early modern Germany: Lindau, 1520-1628. Basingstoke: Palgrave 2001.

Recreation

631 BHANJI S, 'Jesuits and humbugs': religious turmoil in nineteenth-century Exeter. DART 133 (2001) 139-73.

632 HARGREAVES JA, The revival of old dissent: baptists and independents in the parish of Halifax, 1743-1851. HAS 9 (2001) 79-99. 
Holidays and resorts

633 COCKS C, Doing the town: the rise of urban tourism in the United States, 1850-1915. Berkeley: U of California P 2001.

634 LAMBERT R. Patrimoine et identité. Bath 1900-1960. Rennes: UP Rennes 2001. pp 240, il.

\section{Social problems and deviance}

635 HAGEMANN G, London von Scotland yard bis Jack the Ripper: ein fuhrer zu 350 kriminalschauplatzen. Eulen-verl 2000.

636 PICCATO P, City of suspects: crime in Mexico city, 1900-1931. Durham, NC: Duke UP 2001.

\section{Delinquency/crime}

637 ADLER JS, 'Halting the slaughter of innocents': the civilizing process and the surge in violence in turn-of-the-century Chicago. SSH 25 (2001) 29-52.

638 BUCHANAN TC, Rascals on the antebellum Mississippi: African American steamboat workers and the St Louis hanging of 1841. JSocH 34 (2001) 797-816.

639 BURTON A, Urchins, loafers and the cult of the cowboy: urbanization and delinquency in Dar Es Salaam, 1919-61. JAfH 422 (2001) 199-216.

640 DALE E, Local problem or national failure? Murder in New York. RAmH 293 (2001) 352-56.

641 DI BARTOLO L, The geography of reported domestic violence in Brisbane: a social justice perspective. AG 323 (2001) 321-41.

642 LEBOW KA, Public works, private lives: youth brigades in Nowa Huta in the 1950s. CEUrH 102 (2001) 199-219.

643 OGBORN M, This is London! How d'ye like it? JUH 272 (2001) 206-16.

644 PICCATO P, 'El Chalequero' or the Mexican Jack the Ripper: the meanings of sexual violence in turn-of-the-century Mexico City. HAHR (2001) 623-51.

645 SHOEMAKER R, Male honour and the decline of public violence in eighteenthcentury London. SH 262 (2001) 190-208.

646 SYLVESTER RP, City of thieves: Moldavanka, criminality, and respectability in prerevolutionary Odessa. JUH 272 (2001) 131-57.

\section{Poverty and poor relief}

647 ARROM S, Containing the poor: the Mexico City poor houses, 1774-1871. Durham, NC: Duke UP 2001.

648 BRAUN ME, Social change and the empowerment of the poor: poverty representation in Milwaukee's community action programs, 1964-1972. Lanham, Md: Lexington Books 2001.

649 FARMER S, Surviving poverty in medieval Paris: gender, ideology and the daily lives of the poor. Ithaca: Cornell UP 2001.

650 HUFF WG, Entitlements, destitution and emigration in the 1930s Singapore great depression. EcHR LIV 2 (2001) 290-323.

651 SONNENBERG-STERN K, Emancipation and poverty: the Ashkenazi Jews of Amsterdam 1796-1850. New York: St Martins P 2000.

652 STRAIT JB, The impact of compositional and redistributive forces on poverty concentration: the case of Atlanta, Georgia, Metropolitan region, 1980-1990. UAR 37 (2001) 19-42.

Other social problems

653 BEGGS PJ \& SICILIANO F, Spatial relationship between dwelling crowding and selected causes of morbidity in Sydney, Australia, 1994-97. AG 323 (2001) 377-401. 
654 CALDEIRA TPR, City of walls, crime, segregation and citizenship in São Paulo. Berkeley: U of California P 2000.

655 GLEESON B, Domestic space and disability in nineteenth-century Melbourne, Australia. JHG 272 (2001) 223-40.

656 OCHOA EC, Coercion, reform and the welfare state: the campaign against 'begging' in Mexico City during the 1930s. Am 581 (2001) 39-64.

657 PEDERSEN S, The maternalist movement in British colonial policy: the controversy over 'child slavery' in Hong Kong 1917-1941. PaP 170 (2001) 161-202.

658 WAREING J, 'Violently taken away or cheatingly duckoyed': the illicit recruitment in London of indentured servants for the American colonies, 1645-1718. LJ 262 (2001) $1-22$.

\section{Social reform and improvement}

Social reform movements and institutions

659 BRACE JV, The power of porch talks: the Civic Improvement Society of Monroe, Michigan, 1901 to 1914. MHR 27 (2001) 1-31.

660 CARP BL, Fire of liberty: urban voluntary culture and the revolutionary movement. WMQ 58 (2001) 781-818.

661 ELFENBEIN JI, The making of a modern city: philanthropy, civic culture, and the Baltimore YMCA. Gainesville: UP of Florida 2001.

662 SANDERS KM, The Burlington self-survey in human relations: interracial efforts for constructive community change, 1949-1951. AI 60 (2001) 244-69.

663 SHAW RE, A final push for national legislation: the Chicago Freedom Movement. JISHS 94 (2001) 304-32.

664 WALLACE SL, Buffalo's 'prophet of protest': the political leadership and activism of Reverend Dr Bennett W. Smith Jr. ANYLH 25 (2001) 7-44.

Charities

665 BLUM AS, Conspicuous benevolence: liberalism, public welfare, and private charity in Porfirian Mexico City, 1877-1910. Am 581 (2001) 7-38.

666 GORSKY M, Patterns of philanthropy: charity and society in nineteenth century Bristol. London: Royal Historical Society 1999.

667 LEEUWEN MHD, The logic of charity: Amsterdam, 1800-1850. Basingstoke: Macmillan 2000. pp xv +242 .

Social work

668 POMFRET DM, Representations of adolescence in the modern city: voluntary provision and work in Nottingham and Saint-Etienne, 1890-1914. JFH 264 (2001) $455-79$.

\section{Minority groups}

669 BODY-GENDROT S, MARTINIELLO S \& MARTINIELLO M eds, Minorities in European cities: the dynamics of social integration and social exclusion at the neighbourhood level. Basingstoke: Macmillan P 2000.

670 FONDEBRIDER J. Buenos Aires ajena: testimonios de extranjeros de 1536 hasta hoy. Buenos Aires: Emece Editores, 2001.

671 HIGGS D ed, Queer sites, gay urban histories since 1600. London: Routledge 2000.

Racial and ethnic minorities

672 BALDOLI C, The remaking of the Italian community in London: L'Italia Nostra and the creation of a Little Fascist Italy during the 1930s. LJ 262 (2001) 23-34.

673 BILES R, Race and housing in Chicago. JISHS 93 (2001) 31-8. 
674 BLACK G, Health and medical care of the Jewish poor in the east end of London, 1880-1914. JHS 36 (1999-2001) 93-111.

675 BLOBAUM R, The politics of antisemitism in fin-de-siècle Warsaw. JModH 732 (2001) 275-306.

676 BUZZELLI M, From Little Britain to Little Italy: an urban ethnic landscape study in Toronto. JHG 274 (2001) 573-87.

677 CANAAN G, 'Part of the loaf': economic conditions of Chicago's African-American working class during the 1920s. JSocH 35 (2001) 147-74.

678 CAWTHRA B, Ernest Calloway: labor, civil rights, and black leadership. GaH 21 (2000-2001) 4-15.

679 CIOTOLA NP, Spignesi, Sinatra, and the Pittsburgh steelers: Franco's Italian army as an expression of ethnic identity. JSpH 27 (2000) 271-90.

680 DAVIS TJ, Another place, another promise, another paradise? Another perspective on black migration, promised lands, and paradises. ANYLH 25 (2001) 59-78.

681 DE GRAAF BL \& MULROY K, Seeking El Dorado: African Americans in California. Seattle: Autry Museum of Western Heritage, U of Seattle P 2001.

682 DE LEON A, Ethnicity in the sunbelt: Mexican Americans in Houston. College Station, Tx: A \& M UP 2001.

683 FATAL-KNAANI T, The Jews of Pinsk, 1939-1943, through the prism of new documentation. YVS XXIX (2001) 149-82.

684 FITZGERALD MW, Another kind of glory: black participation and its consequences in the campaign for confederate Mobile. AlR 54 (2001) 243-75.

685 FITZSIMMONS L, Adapting Cotton Comes to Harlem: from inter- to intraracial conflict. ANYLH 25 (2001) 45-58.

686 FONER N ed, Islands in the city: West Indian migration to New York city. Berkeley: U of California P 2001.

687 FREUND B, Contracts in urban segregation: a tale of two African cities, Durban (South Africa) and Abidjan (Côte d'Ivoire). JSAS 273 (2001) 527-46.

688 GARCIA M, A world of its own: race, labor, and citrus in the making of Greater Los Angeles, 1900-1970. Chapel Hill: U of North Carolina P 2002.

689 GARCILAZO JM, McCarthyism, Mexican Americans and the Los Angeles Committee for the Protection of the Foreign-Born, 1950-1954. WHQ 32 (2001) 273-95.

690 GERSHENHORN J, Hocutt v. Wilson and race relations in Durham, North Carolina, during the 1930s. NCHR 78 (2001) 275-308.

691 GONZALEZ MARTINEZ E, Los inmigrantes invisibles: condiciones de vida e identidad de los españoles en São Paulo. EIAL 111 (2000) 5-22.

692 GREEN C, Globalization and survival in the black diaspora: the new urban challenge. Albany: State U of New York P 2001.

693 HAAS EF, The expedient of race: Victor H. Schiro, Scott Wilson, and the New Orleans mayoralty campaign of 1962. $\mathrm{LaH} 42$ (2001) 5-29.

694 HIRSCHON R, Heirs of the Greek catastrophe: the social life of Asia minor refugees in Piraeus. New York/Oxford: Berghahn Books 1998. pp xxx + 280, il.

695 JOHNSTON R, FORREST J \& POULSEN M, Sydney's ethnic geography: new approaches to analysing patterns of residential concentration. AG 322 (2001) 149-62.

696 KROPP PS, Citizens of the past? Olvera Street and the construction of race and memory in 1930s Los Angeles. RHR (2001) 35-60.

697 LEE E, Chinese San Francisco, China in America. RAmH 293 (2001) 417-23.

698 MAIRA S, Desis in the house: Indian American youth culture in New York city. Philadelphia: Temple UP 2002.

699 MCKEOWN A, Chinese migrant networks and cultural change: Peru, Chicago, Hawaii, 1900-1936. Berkeley: U of California P 2001.

700 MOHL RA, Race and housing in the postwar city: an explosive history. JISHS 93 (2001) 8-30. 
701 NAZZARI M, Vanishing Indians: the social construction of race in colonial São Paulo. Am 574 (2001) 497-524.

702 NELSON B, Divided we stand: American workers and the struggle for black equality. Princeton: Princeton UP 2001.

703 NYSTROM J, Segregation's last stand: Lester Maddox and the transformation of Atlanta. AtH 45 (2001) 34-51.

704 OLDFIELD J, On the beat: black policemen in Charleston, 1869-1921. SCHM 102 (2001) 153-68.

705 PATRICK RP Jr, A nail in the coffin of racism: the story of the Columbians. GHR 85 (2001) 245-66.

706 PEARSON R, 'A menace to the neighbourhood': housing and African-Americans in Portland, 1941-1945. OHR 102 (2001) 158-79.

707 PLOTKIN W, 'Hemmed in': the struggle against racial restrictive covenants and deed restrictions in post-world war II Chicago. JISHS 93 (2001) 39-69.

708 SHAH N, Contagious divides: epidemics and race in San Francisco's Chinatown. Berkeley: U of California P 2001.

709 SHUMWAY JM, 'The purity of my blood cannot put food on my table': changing attitudes towards interracial marriage in 19th century Buenos Aires. AM 582 (2001) 201-20.

710 SKERRET EL, The Irish of Chicago's Hull-House neighborhood. ChiH (2001) 22-63.

711 STREET P, 'Lynch-law must go!': class, race, culture, and black worker militancy in Chicago's stockyards during the 1930s. JAEH 20 (2000) 18-49.

712 VAHED G, Race or class? community and conflict amongst Indian municipal employees in Durban 1914-1949. JSAS 271 (2001) 105-25.

713 WAITT G, GALEA RM \& RAWSTONE P, Generation and place of residence in the symbolic and lived identity of Maltese in Sydney, Australia. AG 321 (2001) 77-91.

714 WANG X, Surviving the city: the Chinese immigrant experience in the New York City, 1890-1970. Lanham: Rowman \& Littlefield 2001.

715 WEINBERG R, Urban life and modernity among Europe's Jews: two case studies. JUH 274 (2001) 505-10.

Cultural minorities

716 ABRAMOVITCH I \& GALVIN S, Jews of Brooklyn. Hanover: UP of New England 2001.

717 BENARD-OUKHEMANOU A, La communauté juive de Bayonne au XIXe siècle. Biarritz: Atlantica 2001.pp 180, il.

718 BILSKI ED ed, Berlin metropolis, Jews and new culture, 1890-1918. Berkeley: U of California P 1999.

719 DUBIN LC, The port Jews of Habsburg Trieste. Stanford: Stanford UP 1999.

720 EHRLICH W, Zion in the valley: the Jewish community of St Louis. Vol. II, The twentieth century. Columbia: U of Missouri P 2002.

721 FAHERTY WB, The St Louis Irish: an unmatched Celtic community. St Louis: Missouri Historical Society P, U of Missouri P 2001.

722 FRANKE J, Paris, eine neue heimat? Judische emigranten aus Deutschland 1933-1939. Berlin: Drucker \& Humbolt 2000.

723 GRIFFIN P, The people with no name: Ulster's migrants and identity formation in eighteenth-century Pennsylvania. WMQ LVIII 3 (2001) 587-614.

724 LIVSHIN RD, The history of the Harrogate Jewish community. Leeds: Leeds UP 1995 pp xvi + 203, il.

725 LUCONI S, From peasant to white ethnics: the Italian experience in Philadelphia. Albany: State U of New York P 2001.

726 MAGNAGHI RM, Italians in Michigan. Ann Arbor: Michigan State UP 2001.

727 MCBRIDE L, The Reynolds letters: an Irish emigrant family in late Victorian Manchester. Cork: Cork UP 1999. pp viii +107. 
728 MORMINO GR, Immigrants on the hill: Italian-Americans in St Louis, 1882-1982. Columbia: U of Missouri P 2002.

729 RECHTER D, The Jews of Vienna and the First World War. London: Littman Library of Jewish Civilisation 2001. pp xxiii +218.

730 SCHELL W Jr, Integral outsiders: the American colony in Mexico City, 1876-1911. Wilmington: Scholarly Resources 2001.

731 SMITH SE, 'Boogie chillen': uncovering Detroit's African-American cultural history. MHR 27 (2001) 93-108.

732 STERA CM, 'More than ever, we feel proud to be Italians': world war I and the New Haven Colonia, 1917-1918. JAEH 20 (2001) 70-106.

733 THOMPSON TR, Wearin' of the green: the Irish and Saint Patrick's Day in Omaha. $\mathrm{NeH} 81$ (2000) 170-8.

734 TORREZ RJ, A Chicago agricultural colony in northern New Mexico. NMHR 76 (2001) $175-88$.

735 TRIGGER R, The geopolitics of the Irish-Catholic parish in nineteenth-century Montreal. JHG 274 (2001) 553-72.

Majority reactions to minority groups

736 GLAZIER J, 'Transplanted from Kiev to Hoosierdom': how the industrial removal office directed Jewish immigrants to Terre Haute. InMH 92 (2001) 1-30.

737 GREEN A \& MACKINNON M, The slow assimilation of British immigrants into Canada: evidence from Montreal and Toronto, 1901. EEcH 383 (2001) 315-38.

738 WELCH S, Race and place: race relations in an American city. New York/Cambridge: Cambridge UP 2001.

739 WINCH J, 'A person of good character and considerable property': James Forten and the issue of race in Philadelphia's antebellum business community. BuHR 752 (2001) 261-96.

\section{Family life}

740 BRODER S, Tramps, unfit mothers, and neglected children: negotiating the family in nineteenth-century Philadelphia. Philadelphia: U of Pennsylvania P 2002.

741 BRODSKY V, Mobility and marriage family kinship: the family and kinship in early modern London. Oxford: Blackwell 2001.

742 FERRARO J, Marriage wars in late renaissance Venice. Oxford: Oxford UP 2001.

743 GOUREVITCH D \& RAEPSAET-CHARLIER MT, Les femmes dans la Rome antique. Paris: Seuil 2001. pp 280.

744 KELLEHER P, Maternal strategies: Irish women's headship of families in gilded age Chicago. JWH 13 (2001) 80-106.

745 MOON D, 'Unnatural fathers and vixen daughters': a case of incest, San Diego, California, 1894. JWH 39 (2000) 8-16.

746 RAPAPORT Y, Divorce and the elite household in late medieval Cairo. ContC 162 (2001) 201-18.

\section{Gender}

747 BAHRANI Z, Women of Babylon: gender and representation in Mesopotamia. London/ New York: Routledge 2001.

748 BLISS KE, Compromised positions: prostitution, public health and gender politics in revolutionary Mexico city. Philadelphia: Penn State UP 2001.

749 BRANSON S, These fiery Frenchified dames: women and political culture in early national Philadelphia. Philadelphia: U of Pennsylvania P 2001.

750 BUNCH-LYONS B, Contested terrain: African American women migrate to Cincinnati, Ohio, 1900-1950. New York: Routledge 2001.

751 CAINE B, Feminism in London, circa 1850-1914. JUH 275 (2001) 765-78. 
752 CALLOW B, Hurdy gurdy days: a portrait of life in Coventry at the beginning of the twentieth century. Coventry: Women's Research Group 2001. pp 72.

753 CHOJNACKA M, Working women of early modern Venice. Baltimore: Johns Hopkins UP 2001.

754 DRAZNIN Y, Victorian London's middle-class housewife: what she did all day. Greenwood P 1999.

755 FLANAGAN MA, Seeing with their hearts: Chicago women and the vision of the good city, 1871-1933. Princeton: Princeton UP 2002.

756 HEWITT NA, Southern discomfort: women's activism in Tampa, Florida, 1880s-1920s. Urbana: U of Illinois P 2001.

757 HURI-EAMON J, Domestic violence prosecuted: women binding over their husbands for assault at Westminster quarter sessions, 1685-1720. JFH 264 (2001) 435-54.

758 KESSELMAN A, Women's liberation and the left in New Haven, Connecticut, 1968-1972. RHR (2001) 15-34.

759 KIMBLE L Jr, I too serve America: African American women war workers in Chicago, 1940-1945. JISHS 93 (2000-2001) 415-34.

760 LATOUR J, Live! From New York: women construction workers in their own words. LH 422 (2001) 179-89.

761 MARSHALL JE, The changing allegiances of women volunteers in the progressive era, Lafayette, Indiana, 1905-1920. InMH 96 (2000) 242-85.

762 MCKENNA MKL \& ROBERGE RA, Restructuring, gender and employment in flux: a geography of regional change in Cornwall, Ontario. CG 452 (2001) 223-36.

763 MELDRUM T, Domestic service and gender, 1660-1750: life and work in the London household. Harlow: Longman 2000. pp xi +220.

764 MURATA A, Stardust and street of dreams: Chicago girls clubs. ChiH 29 (2001) 21-35.

765 NADELL PS \& SARNA JD eds, Women and American Judaism: historical perspectives. Hanover: UP of New England 2001.

766 NELSON JA, 'Abortions under community control': feminism, nationalism, and the politics of reproduction among New York City's young lords. JWH 13 (2001) 157-80.

767 PARSONS DC, Streetwalking the metropolis, women, the city and modernity. Oxford: Oxford UP 2000.

768 PUTNAM J, A 'test for chiffon politics': gender politics in Seattle, 1897-1917. PHR 69 (2000) 595-616.

769 RAPPAPORT ED, Shopping for pleasure: women in the making of London's West End. Princeton, NJ: Princeton UP 1999.

770 SCHULTZ RL \& HAST A, Women building in Chicago, 1790-1990: a biographical dictionary. Indiana UP 2001.

771 SIMONS W, Cities of ladies: beguine communities in the medieval Low Countries 1200-1565. Philadelphia: U of Pennsylvania P 2001.

772 THOMPSON VE, The virtuous marketplace: women and men, money and politics in Paris, 1830-1870. Baltimore: Johns Hopkins UP 2000.

773 WOLCOTT VW, Gendered perspectives on Detroit history. MHR 27 (2001) 75-92.

774 WOLCOTT VW, Remaking respectability: African American women in interwar Detroit. Chapel Hill: U of North Carolina P 2001.

775 ZBORAY RJ \& ZBORAY MS, Gender slurs in Boston's partisan press during the 1840s. JAS 34 (2000) 413-46.

\section{Economic activity}

\section{Urban economic activity}

Ancient

776 BRESSON A, La cité marchande. Talence: Ausonius 2000. pp 343, il.

777 D'ORAZIO L et al, Nature, origin and technology of natural fibres of textile artefacts recovered in the ancient cities around Vesuvius. JArchS 279 (2000) 745-54. 
778 KIRK T, Genoa and Livorno: sixteenth-and seventeenth-century commercial rivalry as a stimulus to policy development. H 86281 (2001) 3-17.

Medieval and early modern (-1800)

779 AURELL J, Merchants' attitudes to work in the Barcelona of the later middle ages: organisation of working space, distribution of time and scope of investments. JMH 27 3 (2001) 197-218.

780 DELOBETTE E, Les mutations du commerce maritime du Havre 1680-1730 (1ere partie). AdN 1 (2001) 3-70.

781 DIMMOCK S, English small towns and the emergence of capitalist relations, c. 1450-1550. UH 281 (2001) 5-24.

782 GAUCI P, The politics of trade: the overseas merchant in state and society, 1660-1720. Oxford: Oxford UP 2001.

783 JONES ET, Illicit business: accounting for smuggling in mid-sixteenth-century Bristol. EcHR LIV 1 (2001) 17-38.

784 KERMODE JI, Medieval merchants: York, Beverley, and Hull in the later middle ages. Cambridge: Cambridge UP 1998. pp xvii +381 .

785 MCCARTHY M, The forging of an Atlantic port city: socio-economic and physical transformation in Cork, 1660-1760. UH 281 (2001) 25-45.

786 NEWMAN CM, Work and wages at Durham priory and its estates, 1474-1519. ContC 163 (2001) 357-78.

787 SUTTON AF, The shop-floor of the London mercery trade c.1200-c.1500: the marginalisation of the artisan, the itinerant mercer and the shopholder. NMS XLV (2001) 12-50.

788 TOGNETTI S, Uno scambio diseguale, Aspetti dei rapporti commerciali tra Firenze e Napoli nella seconda metà del Quattrocento. ASI 3 (2000) 461-90.

789 WILBY A, Urban development in three northern towns, Kingston-upon-Hull, Pontefract and Guisborough, 1100-1350. ClevH 80 (2001) 25-38.

Modern (1800-)

790 BEBB R, '25th December 1889: Christmas Day lost': furniture making in Merioneth. JMHRS XIII IV (2001) 372-6.

791 BONNELL A, 'Cheap and nasty' German goods, socialism and the 1876 Philadelphia World Fair. IRSH 462 (2001) 207-26.

792 COFFEY WJ \& SHEARMUR RG, The identification of employment centres in Canadian metropolitan areas: the example of Montreal, 1996. CG 453 (2001) 371-86.

793 CRAIG RM, The archaeology of Atlanta's first automobile age. AtH 44 (2000) 5-20.

794 FOLSOM BW, Urban capitalists: entrepreneurs and city growth in Pennsylvania's Lackawanna and Lehigh regions, 1800-1920. U of Scranton P 2001.

795 FORD G, In search of industrial order: the case of Nuremberg's building masters, 1887-1914. GeH 191 (2001) 54-74.

796 GONTARD M, La bourse de Paris (1800-1830). Aix-en-Provence: Edisud 2000.

797 GRANT H \& THILLE H, Tariffs, strategy and structure: competition and collusion in the Ontario petroleum industry, 1870-1880. JEcH 612 (2001) 390-413.

798 HENTSCHEL K \& A, An engraver in nineteenth-century Paris: the career of Pierre Dulos. FH 151 (2001) 64-102.

799 HISE G, 'Nature's workshop': industry and urban expansion in southern California, 1900-1950. JHG 271 (2001) 74-92.

800 HYDE CK, 'Detroit dynamic': the industrial history of Detroit from cigars to cars. MHR 27 (2001) 57-74.

801 JACKSON KC, The Sidgwicks of Skipton: the rise and fall of a family firm (1785-1890). YAJ 73 (2001) 133-53.

802 JACOB M \& REID D, Technical knowledge and the mental universe of Manchester's early cotton manufacturers. CJH XXXVI 2 (2001) 283-304. 
803 LEWIS R, Redesigning the workplace: the North American factory in the interwar period. TC 42 (2001) 665-84.

804 LUPINSKIE-HUVANE L \& SINGER A, The great depression and the New Deal on Long Island, New York. OAHMH 161 (2001) 26-9.

805 MACKIE R, Family ownership and business survival: Kirkcaldy, 1870-1970. BuH 433 (2001) 1-32.

806 MILNE G, Trade and traders in mid-Victorian Liverpool: mercantile business and the making of a world port. Liverpool: Liverpool UP 2000.

807 NGUYEN JH, Laying the foundations: domestic service in Natchez, 1862-1877. JMisH 63 (2001) 35-62.

808 OWUSU F, Urban impoverishment and multiple modes of livelihood in Ghana. CG 45 3 (2001) 387-403.

809 PATTON RL, Mining the Gold Coast: the development of Shaw Industries in Georgia's carpet capital. AtH 45 (2001) 4-20.

810 RAST J, Manufacturing industrial decline: the politics of economic change in Chicago, 1955-1998. JUA 23 (2001) 175-90.

811 RAY I, Imperial policy and the decline of the Bengal salt industry under colonial rule: an episode in the de-industrialisation process. IESHR 2 (2001) 181-205.

812 REVILL G, 'Railway Derby': occupational community, paternalism and corporate culture, 1850-90. UH 283 (2001) 378-404.

813 ROSENBERG DL, Pittsburgh in revolt: sources and artifacts of the struggle against deindustrialization from the UEL/Labor Archives at the University of Pittsburgh. PenH 68 (2001) 367-82.

814 SALVATORE R, The normalization of economic life: representations of the economy in golden-age Buenos Aires, 1890-1913. HAHR 811 (2001) 1-44.

815 SOLA-CORBACHO JC, Urban economies in the Spanish world: the cases of Madrid and Mexico City at the end of the eighteenth century. JUH 275 (2001) 604-32.

816 STIRITZ M, 'The romance of Alaska sealskin': the fur trade in twentieth-century St Louis. GaH 21 (2001) 30-40.

817 WALKER R \& LEWIS RD, Beyond the crabgrass frontier: industry and the spread of North American cities, 1850-1950. JHG 271 (2001) 3-19.

\section{Industry}

818 CORDONNIER A, Une industrie fragile: le raffinage du sucre à Lille (1675-1790). $R N$ 341 (2001) 541-76.

819 DAUMALIN X \& RAVEUX O, Marseille (1831-1865). Une révolution industrielle entre Europe du Nord et Méditérranée. AHSS 1 (2001) 153-76.

820 MELOSI MV, Effluent America: cities, industry, energy, and the environment. Pittsburgh: U of Pittsburgh P 2001.

\section{External trade}

821 STABEL P ed, International trade in the Low countries (14th-16th centuries): merchants, organisations, infrastructure. (Studies in urban social, economic and political history of the medieval and modern Low Countries, vol. 10). Leuven: Garant 2000.

\section{Internal trade and services}

822 GINET J-P, Les métiers d'autrefois à Romans-sur-Isère. Veurey: Le Dauphiné 2000. pp 208, il.

823 GROSSE R, Reliques du Christ et foires de Saint-Denis au XIe siècle. RHEF 219 (2001) 357-76

824 WALSH C, Les relations entre les commerçants et les propriétaires dans les galeries marchandes à Londres (XVIIe-XVIIIe siècles). HUr 4 (2001) 27-46. 
825 YOUNGE M ed, Ripon market place: the evolution of the centre of a historic Yorkshire market town. Ripon: Ripon Historical Society and the Ripon, Harrogate and District Family History Group 2001. pp xiv + 150, il.

Food supply

826 INGRAHAM AT, Henry Weinhard and Portland's city brewery. OHQ 102 (2001) 180-95.

827 MIDDLETON S, 'How it came that the bakers bake no bread': a struggle for trade privileges in seventeenth-century New Amsterdam. WMQ LVIII 2 (2001) 347-72.

828 SOLOMIDOU-IERONYMIDOU M, Medieval sugar mills of Episkopi Serayia and Kolossi, Cyprus. AJA (2001) 254.

829 STRUM H, Famine relief from the garden city to the green isle. JISHS 93 (2000-2001) 388-414.

Finance, banking and insurance

830 MATTEI E \& MORICE A, La Bourse et son Palais. Paris: A Biro 2001. pp 192, il.

Other non-municipal services

831 GUINNESS M, The Guinness spirit: brewers and bankers, ministers and missionaries. London: Hodder and Stoughton 1999. pp xvii +525.

\section{Working conditions}

832 JOHNSTON R \& MCIVOR A, 'Dust to dust': oral testimonies of asbestos-related disease on Clydeside c.1930 to the present. OH 291 (2001) 48-61.

833 SEAGER DR, Barre, Vermont granite workers and the struggle against silicosis, 1890-1960. LH 421 (2001) 61-79.

\section{Labour organization}

834 BAE Y, Labor in retreat: class and community among men's clothing workers of Chicago, 1871-1929. New York: State U of New York P 2001.

Guilds

835 FARNHILL K, Guilds and the parish community in late medieval East Anglia, c.1470-1550. Woodbridge: York Medieval 2001.

Trade unions

836 HILSON M, Labour politics in a naval dockyard: the case of Karlskrona, Sweden, c.1880-1925. IRSH 463 (2001) 341-69.

837 MARTIN CT, New unionism at the grassroots: the Amalgamated Clothing Workers of America in Rochester, New York, 1914-29. LH 423 (2001) 237-53.

838 MILIKAN W, A union against unions: the Minneapolis citizens alliance and its fight against organised labor, 1903-1957. St Paul: Minnesota Historical Society P 2001.

839 SMITH M, 'Let's make Detroit a union town': the history of labor and the working class in the motor city. MHR 27 (2001) 157-76.

Strikes and lockouts

840 KUHN CM, Contesting the new south order: the 1914-1915 strike at Atlanta's Fulton mills. Chapel Hill: U of North Carolina P 2001.

841 YEATES P, Lockout, Dublin 1913. Dublin: Gill \& Macmillan 2001.

Redundancy and unemployment

842 WAUGH J, 'Give this man work!': Josephine Shaw Lowell, the Charity Organization Society of the city of New York, and the depression of 1893. SSH 25 (2001) 217-46. 
Company towns

843 POREMBA DL, Detroit, a motor city history. Arcadia 2001.

844 VAN SITTERT L, 'Velddrift': the making of a South African company town. UH 282 (2001) 194-217.

\section{Communications}

Inter-urban communications

845 JACKSON RW, Rails across the Mississippi: a history of the St Louis Bridge. Urbana: U of Illinois P 2001.

Roads

846 PLATT E, Leadville: a biography of the A40. London: Picador 2000. pp 293, il.

Shipping

847 CHAMAY J, Ostia: port de Rome antique. Geneva: Georg/Musée d'art et d'histoire de Genève 2001. pp 132, il.

848 HOGG PL, The early history of the port of Hartlepool, Part 1. ClevH 81 (2001) 3-12.

849 JEFFREY R, The herald book of the Clyde. Edinburgh: Black \& White Publishing 1998. pp 166, il.

850 LASS WE, The fate of steam boats: a case study of the 1848 St Louis fleet. MisHR 96 (2001) 2-15.

851 MANNEVILLE P ed, Des villes et des ports, la mer et les hommes: actes du 124e congrès des société historiques et scientifiques, section d'histoire moderne et contemporaine, Nantes 1999. Paris: Ed. du CTHS 2001. pp 314.

852 MUNRO F \& SLAVEN T, Networks and markets in Clyde shipping: the Donaldsons and the Hogarths, 1870-1939. BuH 432 (2001) 19-50.

853 RONDEL E, Brest: un port pour l'Amérique 1917-1919. Fréhel: Astoure 2001. il.

854 TREGLOWN T comp, Portleven: the history of England's most southerly mainland port. Chippenham: T Treglown 2000. pp 72, il.

Canals and waterways

855 BACKOUCHE I, La trace du fleuve: la Seine et Paris, 1750-1850. Paris: Ecole des Hautes Etudes en Sciences Sociales 2000. pp 430, il.

856 LE MAREC Y, Nantes au XIXe siècle: du fleuve à la ville. Laval: Siloë 2001. pp 111, il.

Air

857 BEDNAREK JRD, America's airports: airfield development, 1918-1947. College Station: Texas A \& M UP 2001.

Roads and streets

858 BLUA G et al, Marseille: un pont pour le troisième millenaire. Marseille: Autre Temps 2001. pp 64, il.

859 FABRE M, Les rues de Pau des origines à nos jours: dictionnaire historique et biographique. Pau: Librairie des Pyrénées \& de la Gascogne 2000. pp 197.

860 GALY R, Les rues de Bordeaux des origines à nos jours. Dictionnaire historique et biographique (3rd ed.). Belin-Bellier: Princi Neger 2001.

861 POZZO DI BORGO R, Les Champs Elysées: trois siècles d'histoire. Paris: La Martinière 2001 (réed). pp 400, il.

862 WHITE LJ, Dividing highway: citizen activism and interstate 66 in Arlington, Virginia. WH 13 (2001) 52-67, 93-5. 
Public transport

863 ARRIVETZ J, Lyon du tram au tram. Chanac: Régordane 2001. pp 112, il.

864 JACOBS G, Le métro de Paris: un siècle de matériel roulant. Paris: Vie du rail 2001. pp 221 , il.

865 L'HOST H et al, Histoire des tramways à Bordeaux. Breil sur Roya: Cabri 2000. pp 280, il.

\section{Politics and administration \\ Urban politics and administration}

866 BEITO DT, GORDON P \& TABARROK A eds, The voluntary city: choice, community, and civil society. Ann Arbor: U of Michigan P 2002.

867 CAHSIN EJ \& ESKEW GT eds, Paternalism in a Southern city: race, religion, and gender in Augusta, Georgia. Athens: U of Georgia P 2001.

868 DALE E, The rule of justice: the people of Chicago versus Zephyr Davis. Columbus: Ohio State UP 2001.

869 FAIRBANKS RB \& MOONEY-MELVIN P, Making sense of the city: local government, civic culture and community life in urban America. Columbus: Ohio State UP 2001.

870 FERGUSON KJ, Black politics in New Deal Atlanta. Chapel Hill: U of North Carolina P 2002.

871 IMBRUGLINA G ed, Naples in the eighteenth century: the birth and death of a nation state. Cambridge: Cambridge UP 2000.

872 LEAR J, Workers, neighbours, and citizens: the revolution in Mexico city. Lincoln: U of Nebraska P 2001.

873 SABATO H, The many and the few: political participation in republican Buenos Aires. Stanford: Stanford UP 2001.

874 THOMPSON HA, Whose Detroit? Politics, labor, and race in a modern American city. Ithaca: Cornell UP 2001.

875 WARREN RA, Vagrants and citizens: politics and the masses in Mexico city from colony to republic. Wilmington: Scholarly Resources 2001.

876 WINGERD ML, Claiming the city: politics, faith, and the power of place in St Paul. Ithaca: Cornell UP 2001.

Ancient

877 ARNASON JP \& MURPHY P, Agon, logos, polis: the Greek achievement and its aftermath. Stuttgart: Franz Steiner Verlag 2001.

878 BALOT R, Greed and injustice in classical Athens. Princeton: Princeton UP 2001.

879 BAMBAN R, Dynasties of ancient Elam. Woodland Hills: SN 2000.

880 CAREY C, Democracy in classical Athens. Bristol: Classical P 2001.

881 HERRING E \& LOMAS K, The emergence of state identities in Italy in the first millennium BC. London: $U$ of London 2000.

882 MAYR-HARTING H, Liudprand of Cremona's account of his legation to Constantinople (968) and Ottoman imperial strategy. EHR 116467 (2001) 539-556.

Medieval and early modern (-1800)

883 ARCHER IW, The burden of taxation on sixteenth-century London. HJ 443 (2001) 599-627.

884 ARCHER IW, The government of London, 1500-1650. LJ 261 (2001) 19-28.

885 Barbara F, Gleichheitsdenken in deutschen Städten des 12. bis 15. Jahrhunderts. geistesgeschichte, quellensprache, gesellschaftsfunktion. Cologne: Böhlau 2000.

886 BARRON CM, The government of London: the formative phase, 1300-1500. LJ 261 (2001) 9-18.

887 BLANQUIE C, La verification des dettes de Bordeaux (1665-1670): La Fronde, quinze ans après. AdM 113233 (2001) 39-57. 
888 CARPIO D, La tierra de Córdoba. el dominio jurisdiccional de la ciudad durante la baja edad media. Córdoba: Universidad de Córdoba 2000.

889 CASTIGLIONE C, Political culture in seventeenth-century Italian villages. JInH 314 (2001) 523-52.

890 CORTEGUERA LR, Popular politics in composite monarchies: Barcelona artisans and the campaign for a papal bull against hoarding (1580-5). SH 261 (2001) 22-39.

891 COSSAR R, The quality of mercy: confraternities and public power in medieval Bergamo. JMH 272 (2001) 139-57.

892 DOTSON JE, Foundations of Venetian naval strategy from Pietro II Orseolo to the Battle of Zonchio, 1000-1500. V 32 (2001) 113-25.

893 GAUTELET M, Entre France et Empire. Metz, une conscience municipale en crise à l'aube des temps modernes 1500-1526. RH 617 (2001) 5-46.

894 HARDING V, Controlling a complex metropolis, 1650-1750: politics, parishes and powers. LJ 261 (2001) 29-37.

895 INNES M, State and society in early middle ages: the middle Rhine Valley, 400-1000. Cambridge: Cambridge UP 2000.

896 KEENE D, Roots and branches of power, 1000-1300. LJ 261 (2001) 1-8.

897 LILLICH MP, Art and politics in a late medieval city state. JEH (2001) 364.

898 MANJOT D \& SANCHEZ MARTINEZ M, La fiscalité des villes au moyen âge (France méridionale, Catalogne, Castille). 3: La redistribution de l'impôt. Toulouse: Privat 2001. pp 200.

899 MARTIN J \& ROMANO D eds, Venice reconsidered: the history and civilization of an Italian city-state, 1297-1797. Baltimore: Johns Hopkins UP 2000.

900 PREVENIER W \& DE HEMPTINNE T, La diplomatique urbaine en Europe au moyen âge, actes du congrès de la Commission internationale de diplomatique, Gand, 25-29 août 1998. Leuven: Garant 2000.

901 SACKS DH, Iniquity and regeneration: urban life and the reformation in England. JBS 402 (2001) 268-79.

902 WILLIAMS IL, The urbanity of Marlborough: a Wiltshire town in the seventeenth century. WS 94 (2001) 139-47.

903 WITHINGTON P, Two Renaissances: urban political culture in post-Reformation England reconsidered. HJ 441 (2001) 239-67.

Modern (1800-)

904 AUGUST A, A culture of consolation? Rethinking politics in working-class London, 1870-1914. HR 74184 (2001) 193-219.

905 BECKETT J, Frustrated ambition: the Nottingham boundary extension of 1933. ThS 105 (2001) 171-83.

906 BIRCH S, The Holbrook bequest for commemorative plaques: tradition, narrative and 'local patriotism' in Victorian Nottingham. ThS 105 (2001) 155-70.

907 BROWN CC, One step closer to democracy: African American voting in late nineteenth-century Cambridge. MdHM 95 (2000) 428-37.

908 BUCKI C, Bridgeport's socialist new deal, 1915-36. Urbana: U of Illinois P 2001.

909 BUNTING T \& FILION P, Uneven cities: addressing rising inequality in the twentyfirst century. CG 451 (2001) 126-31.

910 Burton RDE, Blood in the city: violence and revelation in Paris, 1789-1945. Ithaca/London: Cornell UP 2001. pp xv + 395, il.

911 DALE E, Not simply black and white: jury power and the law in late-nineteenth century Chicago. SSH 25 (2001) 7-28.

912 DALY G, Inside Napoleonic France: state and society in Rouen, 1800-1815. Aldershot: Ashgate 2001. pp xii +290 , il.

913 DAVIS J, London government 1850-1920: the metropolitan board of works and the London County Council. LJ 261 (2001) 47-56. 
914 DOWDY GW, 'A business government by a business man': E. H. Crump as a progressive mayor, 1910-1915. THQ 40 (2001) 162-75.

915 EINHORN RL, Property rules: political economy in Chicago, 1833-1872. Chicago: Chicago UP 2001.

916 FERNANDES E, The legalisation of favelas in Brazil: problems and prospects. TWPR 222 (2000) 167-87.

917 FISCHER V, Stadt und burgertum in Kurhessen: kommunalreform un wandel der stadtischen gesellschaft 1814-1848. Kassel: Verein fur hessische Gescgichte and Landeskunde 2000.

918 FROST J, An interracial movement of the poor: community organizing and the new left in the 1960s. New York: New York UP 2001.

919 GOUNARIS BC, From peasants into urbanites, from village into nation: Ottoman Monastir in the early twentieth century. EHQ 311 (2001) 43-63.

920 HOLLI MG, The American mayor: the best and worst big-city leaders. University Park: Pennsylvania State UP 1999.

921 HOLLI MG, The wizard of Washington: Emil Hurja, Franklin Roosevelt, and the birth of public opinion polling. New York: Palgrave 2002.

922 HOLLI MG \& OLSSON NW, Swedish voters in Chicago, 1888: based on the voter registration of 1888. Winter Park: SAG 1999.

923 HURD M, Public sphere, public mores, and democracy, 1870-1914. Ann Arbor: U of Michigan P 2000.

924 JEONG W, The urban development politics of Seoul as a colonial city. JUH 272 (2001) $158-77$.

925 JOANA J, La commune contre le municipalisme. Débat public et politiques municipales à Avignon sous la IIIe République (1884-1903). Gen 43 (2001) 89-111.

926 LEFRANCAIS G, Étude sur le mouvement communaliste: à Paris en 1871. Cœuvres et Valséry: Ressouvenances 2001. pp 520.

927 MASCLET O, Une municipalité communiste face à l'immigration algérienne et marocaine: Gennevilliers, 1950-1972. Gen 45 (2001) 150-63.

928 MAYCOCK GH, The triumph of Siegfried Bettmann, mayor of Coventry, 1913-1914. Coventry: Coventry Branch of Historical Association 2000. pp vi + 74, il.

929 MCDANIEL GW, Trying Iowa's Civil Rights Act in Davenport: the case of Charles and Ann Toney. AI 60 (2001) 231-43.

930 NESS I \& EIMER S eds, Central labor councils and the revival of American unionism: organising for justice in our communities. Armonk, NY: ME Sharpe 2001.

931 QUINAULT R, From national to world metropolis: governing London, 1750-1850. LJ 261 (2001) 38-46.

932 RUBIO PF, A history of affirmative action, 1619-2000. Jackson: U of Mississippi P 2001.

933 SCHNEIDER O, Nürnbergs grosse zeit: reichsstädtische renaissance, europäischer humanismus. Cadolzburg: Ars Vivendi 2000.

934 SIMPSON DW, Rogues, rebels and rubber stamps: the politics of the Chicago city council from 1863 to the present. Westview 2001.

935 SPINKS P, 'The War Courts': the Stratford-upon-Avon borough tribunal 1916-1918 WarH XI $4(2000 / 2001) 150-8$.

936 TRAVERS T, The years of borough government: 1986 to 2000. LJ 261 (2001) 69-80.

937 WERNER RD, The New South creed and the limits of radicalism: Augusta, Georgia, before the 1890s. JSH 62 (2001) 573-600.

938 WISEMAN WG, A brief history of Kendal petty sessions. CWAAS 3rd ser. 1 (2001) 105-22.

939 WOLFF L, Venice and the Slavs: the discovery of Dalmatia in the age of enlightenment. Stanford: Stanford UP 2001. pp x + 408, il.

940 YOUNG K, London government 1920-1986: ideal and reality. LJ 261 (2001) 57-68. 


\section{Urban politics at national level}

941 ASH TG, We the people: the revolution of ' 89 witnessed in Warsaw, Budapest, Berlin and Prague. London: Penguin Books 1999. pp 168.

942 GERTEIS LS, Civil war St Louis. Lawrence: UP of Kansas 2001.

943 GINSBURG LM, Israelites in blue and gray: unchronicled tales from two cities. Lanham: UP of America 2001.

944 GRATHWOL RP \& MOORHUS D, Berlin and the American military, a cold war chronicle. New York: New York UP 2000.

945 LUTZ C, Home front: a military city and the American twentieth century. Boston: Beacon 2001.

946 WHITING C, Britain under fire: the bombing of Britain's cities, 1940-1945. London: Leo Cooper 1999. pp 208, il.

\section{Aspects of urban administration}

947 HERTZOG T, Rendre la justice à Quito 1650-1750. Paris: L'Harmattan 2001. pp 363.

948 LAFI N, Ville arabe et modernité administrative municipale: Tripoli (Libye actuelle), 1795-1911. HUr 3 (2001) 149-68.

949 SOURIAC PJ, Les 'urgeans' affaires de la ville. Défendre Toulouse durant la première guerre de religion. HUr 3 (2001) 39-66.

Public health - hospital development

950 BIGELOW AC, Columbus's pioneer doctor John M. Edmiston: the fabric of his life and death. OhH 110 (2001) 5-25.

951 BROOKE E, Public health in Hull, 1881-1901. EYH 2 (2001) 1-7.

952 CALHOON CM, Tuberculosis, race, and the delivery of health care in Harlem, 1922-1939. RadH (2001) 101-20.

953 DIACK L, Myths of a beleagured city: Aberdeen and the typhoid outbreak of 1964 explored through oral history. OH 291 (2001) 62-72.

954 GRUFFUDD P, 'Science and the stuff of life': modernist health centres in 1930s London. JHG 273 (2001) 395-416.

955 HEDENBORG S, To breastfeed another woman's child: wet-nursing in Stockholm, 1777-1937. ContC 163 (2001) 399-422.

956 HOFFMAN SJ, Progressive public health administration in the Jim Crow south: a case study of Richmond, Virginia, 1907-1920. JSocH 35 (2001) 175-94.

957 MCHUGH TJ, The Hôpital Général, the Parisian elites and crown social policy during the reign of Louis XIV. FH 153 (2001) 235-53.

958 POMFRET D, The city of evil and the great outdoors: the modern health movement and the urban young, 1918-40. UH 283 (2001) 405-27.

959 TEIXEIRA LA, Da trasmissão hídirca a culicidiana: a febre amarela na sociedad de medicina e cirugia de São Paulo. RBH 2141 (2001) 217-42.

960 THORNTON P \& OLSON S, A deadly discrimination among Montreal infants, 1860-1900. ContC 161 (2001) 95-135.

961 WALLSGROVE SG, The hospital of St John the Baptist, Warwick, and its seventeenthcentury rebuilding. WarH XI 4 (2000/2001) 129-40.

962 WEISZ G, Reconstructing Paris medicine. BHM 751 (2001) 105-19.

\section{Welfare}

963 KATZ MB, The price of citizenship: redefining America's welfare state. New York: Metropolitan Books 2001.

964 SHAPELY P, Urban charity, class relations and social cohesion: charitable responses to the cotton famine. UH 281 (2001) 46-64. 
965 WESTON NP, 'Frecher Versuch das Arbeitshaus zu zerstoren': an introduction to vagrancy and workhouses in New Orleans. LaH (2000) 467-81.

Police

966 GLAESER A, Divided in unity, identity, Germany and the Berlin police. Chicago: U of Chicago P 2000.

967 JACQUIN F, Un empoisonnement à Paris: l'empoisonnement du sieur Vaux (1742). HES 1 (2001) 23-36.

968 LE COUR GRANMAISON O et al eds, Le 17 octobre 1961, un crime d'État à Paris. Paris: La Dispute 2001. pp 288, il.

969 LEFEBVRE B, La terreur et ses victimes dans une ville de la frontière nord. L'exemple de Douai (juin 1793-juillet 1794). RN 342 (2001) 777-800.

970 POSTIC M, Carrier et la terreur de Nantes: récit. Paris: L’Harmattan 2001. pp 302.

Fire

971 SLAP AL, 'The strong arm of the military power of the United States': the Chicago fire, the constitution, and reconstruction. CWH 47 (2001) 146-63.

\section{Public utilities}

972 JACOBSON CD, Ties that bind: economic and political dilemmas of urban utility networks, 1880-1990. Pittsburgh: U of Pittsburgh P 2001.

973 JAKLE JA, City lights: illuminating the American night. Baltimore: Johns Hopkins UP 2001.

Water

974 ALLEN D, The public water supply of Ipswich before the Municipal Corporations Act of 1835. SuffIAH XL 1 (2001) 31-54.

975 BOUCHERON P, Water and power in Milan, c.1200-1500. UH 282 (2001) 180-93.

976 KEENE D, Issues of water in medieval London to c.1300. UH 282 (2001) 161-79.

977 MAGNUSSON R, Water technology in the middle ages: cities, monasteries, and water works after the Roman empire. Baltimore: Johns Hopkins University 2001.

978 TROESKEN W, Race, disease and the provision of water in American cities, 1889-1921. JEcH 613 (2001) 750-76.

\section{Shaping the urban environment}

\section{Research methods, aids and materials}

Theory

979 DREIER P, MOLLENKOPF J \& SWANSTROM T, Place matters: metropolitics for the twenty-first century. Lawrence: UP of Kansas 2001.

\section{Town planning and environmental control}

980 BEATLEY T, Green urbanism: learning from European cities. Washington DC: Island P 2000.

Ancient

981 DURET L \& NERAUDAU JP, Urbanisme et métamorphoses de la Rome antique. Paris: Belles-lettres 2001 (réed). pp 440.

982 LAFON X, Libre propos: sur les fondations coloniales romaines. HUr 3 (2001) 169-87.

983 MALVILLE J \& GUJRAL L, Ancient cities, sacred skies: cosmic geometrics and city planning in ancient India. New Delhi: Aryan Books International 2000. 
Medieval and early modern (-1800)

984 MCKELLAR E, The birth of modern London: the development and design of the city 1660-1720. Manchester: Manchester UP 1999.

985 WITHINGTON P, Views from the bridge: revolution and restoration in seventeenthcentury York. PaP 170 (2001) 121-51.

Modern (1800-)

986 BLOOM N, The federal Icarus: the public rejection of 1970s national suburban planning. JUH 281 (2001) 55-71.

987 CHOAY F, LANDAU B \& GAUTHIER VSM, Haussmann, Georges Eugene, memoires. Paris: Seuil 2000.

988 DEBARBIEUX B, Chamonix-Mont-Blanc, 1860-2000: les coulisses de l'aménagement. Servoz: Edimontagne 2001 (new ed). pp 207.

989 EMBRY J, North Logan: a town without a plan. UHQ 69 (2001) 139-51.

990 FONSECA M, SOBREIRA F, RAINHO ME \& OLIVEIRA M, Unbridled development of urban space and its implications for the preservation of landmarks: the Morro da Archaeological Site, Ouro Preto, Brazil. C 186 (2001) 381-9.

991 FREESTONE R ed, Urban planning in a changing world: the twentieth-century experience. New York: E \& FN Spon 2000.

992 GEORGE S, Liverpool park estates: their legal basis, creation and early management. Liverpool: Liverpool UP 2000.

993 GIBELIN M \& STEINBRECHER B, Clermont et Mont-Ferrand 1900-1920. ClermontFerrand: Ed. de Borée 2001. pp 180, il.

994 GILLETTE H Jr, Towards effective environmental intervention in cities: Roy Lubove's evolving critique of urban planning. PenH 68 (2001) 325-36.

995 GORDON DLA, From noblesse oblige to nationalism: elite involvement in planning Canada's capital. JUH 281 (2001) 3-34.

996 GOUBERT JP, La ville, miroir et enjeu de la santé: Paris, Montréal et Alger au XIXe siècle. HES 3 (2001) 355-76.

997 HARTER H, Les ingénieurs des travaux publics et la transformation des métropoles américaines: 1870-1910. Paris: Publications de la Sorbonne 2001. pp 444.

998 HEIM CE, Leapfrogging, urban sprawl and growth management: Phoenix, 1950-2000. AJES 60 (2001) 245-83.

999 KNEPPER CD, Greenbelt, Maryland: a living legacy of the new deal. Baltimore: Johns Hopkins UP 2001.

$1000 \mathrm{KOCH}$ N, Koch + partner: achitekten and stadtplaner, 1970-2000 = architects and urban planners, 1970-2000. Basle/Boston: UP 1999.

1001 LADD B, Socialist planning and the rediscovery of the old city in the German democratic republic. JUH 275 (2001) 584-603.

1002 MOHL R, Roy Lubove and American urban history: a review essay on Pittsburgh's post-steel era. PenH 68 (2001) 354-62.

1003 MORELLO J, BUZAI GD, BAXENDALE CA, RODRIGUEZ AF, MATTEUCCI SD, GODAGNONE RE \& CASAS RR, Urbanization and the consumption of fertile land and other ecological changes: the case of Buenos Aires. EU 122 (2000) 119-31.

1004 MULLER EK, Lubove's Pittsburgh. PenH 68 (2001) 336-53.

1005 RUSSELL RD Jr, Unrealized visions: Medford and the city beautiful movement. $O H Q$ 102 (2001) 196-209.

1006 VALLAT C, Villes neuves de l'Italie fasciste: usages et limites d'un outil de propagande. HUr 4 (2001) 161-82.

1007 VENKATESH S, Chicago's pragmatic planners: American sociology and the myth of community. SSH 25 (2001) 275-317.

1008 WHITEHAND JWR \& CARR CMH, The creators of England's inter-war suburbs. UH 282 (2001) 218-34. 
1009 EXPOSITION MUSEE DE VALENCE, Utopies urbaines: exposition, Valence, Musée de Valence, 25 janvier-20 avril 2001. Paris: Réunion des musées nationaux 2001. pp 192, il.

\section{Housing improvement}

Public housing provision

1010 CIELATKOWSKA R, Architecture and urban design of social housing estates in Gdansk from the interwar period. Gdansk: PW Mirex Leszek Chmielwsji 2000.

1011 SIDNEY MS, Images of race, class, and markets: rethinking the origin of US fair housing policy. JPH 132 (2001) 181-214.

Slum clearance

1012 HARTER S, Hong Kong's dirty little secret: clearing the walled city of Kowloon. JUH 271 (2000) 92-113.

Urban renewal

1013 BAUMAN JF, Community building versus housing reform: Roy Lubove and the history of housing reform in the United States. PenH 68 (2001) 293-313.

1014 GOTHAM KF, A city without slums: urban renewal public housing and the downtown revitalization in Kansas City, Missouri. AJES 60 (2001) 285-316.

1015 HAZAREESINGH S, Colonial modernism and the flawed paradigms of urban renewal: uneven development in Bombay, 1900-25. UH 282 (2001) 235-55.

1016 JENKINS WD, Before downtown: Cleveland, Ohio, and urban renewal, 1949-1958. JUH 274 (2001) 471-96.

1017 MCKEE GA, Liberal ends through illiberal means; race, urban renewal, and community in the Eastwick section of Philadelphia, 1949-1990. JUH 275 (2001) 547-83.

1018 PRITCHETT WE, Race and community in postwar Brooklyn: the Brownsville neighborhood council and the politics of urban renewal. JUH 274 (2001) 445-70.

\section{New and expanded towns}

1019 ROGERS MF, John Nolen \& Mariemont: building a new town in Ohio. Baltimore: Johns Hopkins UP 2001.

1020 SIMMONDS AGV, Conservative governments and the new town housing question in the 1950s. UH 281 (2001) 65-83.

\section{Urban culture}

\section{Urban culture and entertainment}

1021 JARVIS AR, Opportunity, experience, and recognition: black participation in Philadelphia's New Deal arts projects, 1936-1942. JNH 85 (2000) 241-59.

1022 SPANG RL, The invention of the restaurant: Paris and modern gastronomic culture. Cambridge, Mass: Harvard UP 2000.

1023 WHITE E, The flaneur: a stroll through the paradoxes of Paris. London: Bloomsbury Publishers 2001.

1024 WILDER CS, In the company of black men: the African influence on African American culture in New York City. New York: New York UP 2001.

Ancient

1025 PAILLER JM, Les mots de la Rome antique. Toulouse: UP du Mirail-Toulouse 2001. pp 128. 
Medieval and early modern

1026 BORSAY P, HIRSCHFELDER G \& MOHRMANN R-E eds, New directions in urban history: aspects of European art, health, tourism and leisure since the enlightenment. Waxmann 2000.

1027 DURY C, Villes, histoires et culture(s). MoA 1 (2001) 101-12.

1028 KISBY F, Music and musicians in renaissance towns. Cambridge/New York: Cambridge UP 2001.

1029 KOHL BG, Culture and politics in early renaissance Padua. Aldershot: Ashgate 2001.

1030 MORRALL A, Jörg Breu the elder: art, culture, and belief in reformation. Augsburg/ Aldershot: Ashgate 2001.

1031 THURBER TB \& RANDOLPH A, Antiquity in Rome from the renaissance to the age of enlightenment: selections from Dartmouth's collections. Hanover: Dartmouth College 2001.

Modern

1032 ABBOT C, Portland: civic culture and civic opportunity. OHQ 102 (2001) 6-21.

1033 BLUME M, A French affair: the Paris beat, 1965-1998. New York: Free P 1999. pp xx + 279 , il.

1034 BOYLE K, The ruins of Detroit: exploring the urban crisis in the motor city. MHR 27 (2001) 109-28.

1035 CROLL A, Civilising the urban: popular cultural and public space in Merthyr, c.1870-1914. U of Wales P 2000.

1036 FEENBERG A \& FREEDMAN J, When poetry ruled the streets: the French May events of 1968. New York: U of New York P 2001.

1037 GEYER MH \& PAULMANN J eds, The mechanics of internationalism: culture, society and politics form the 1840s to the First World War. Oxford: Oxford UP 2001.

1038 GOSSMAN L, Basel in the age of Burkardt a study in unseasonable ideas. Chicago/London: U of Chicago P 2000. pp xii + 608, il.

1039 JOSEPH G, RUBENSTEIN A \& ZOLOV E eds, Fragments of a golden age: the politics of culture in Mexico since 1940. Durham, NC: Duke 2001.

1040 LOEFFELHOLZ M, The religion of art in the city at war: Boston's public poetry and the great organ, 1863. ALH 13 (2001) 212-41.

1041 SANDRONI C, Feitiço decente: transformaçoes do samba no Rio de Janeiro, 1917-1933. Rio De Janeiro: Editora UFRJ 2001.

1042 SCOTT WB and RUTKOFF PM, New York modern: the arts and the city. Baltimore: Johns Hopkins UP 2001.

1043 SEIGEL J, Bohemian Paris, culture, politics and the boundaries of bourgeois life, 1830-1930. Baltimore: Johns Hopkins UP 1999.

1044 STANONIS A, 'Always in costume and mask': Lyle Saxon and New Orleans tourism. LaH 42 (2001) 31-57.

1045 THOMPSON S, Ah Toucoutou, ye conin vous: history and memory in Creole New Orleans. AQ 53 (2001) 232-66.

1046 TUNBRIDGE JE, Ottawa's Byward market: a festive bone of contention? CG 453 (2001) 356-70.

1047 WARD J, Weimar surfaces: urban visual culture in 1920s Germany. Berkeley: U of California P 2001.

\section{Forms of entertainment}

1048 BJORN L \& GALLERT J, Before Mowtown: a history of Jazz Detroit, 1920-60. Ann Arbor: U of Michigan P 2001.

1049 FULLER KH, At the picture show: small-town audiences and the creation of movie fan culture. Charlottesville: UP of Virginia 2001.

1050 ROBERT JN, Les plaisirs à Rome. Paris: Payot 2001. pp 304. 
1051 SUHOR C, Jazz in New Orleans: the post-war years through 1970. Lanham: Scarecrow Press, Rutgers Institute of Jazz Studies 2001.

Mass entertainment

1052 DAUTRESME O, La promenade: un loisir urbain universel? L'exemple du PalaisRoyal à Paris à la fin du XVIIIe siècle. HUr 3 (2001) 83-102.

1053 EL-WAKIL L \& VAISSE P eds, Genève 1896 regards sur une exposition nationale. Geneva: Georg 2000. pp 189, il.

Theatre

1054 BRENDEL-PERPINA I, Heinrich Heine und das Pariser Theater zur Zeit der Julimonarchie. Bielefeld: Aisthesis 2000.

1055 COCKIN K \& CAMPLING J, Women and theatre in the age of suffrage: the pioneer players 1911-1925. Basingstoke: Palgrave 2001.

1056 EHRSTINE G, Theater, culture, and community in reformation Bern, 1523-1555. Boston: Brill 2001.

1057 KARR D, 'Thoughts that flash like lightning': Thomas Holcroft, radical theatre, and the production of meaning in 1790s London. JBS 403 (2001) 324-56.

1058 MARLOWE E, Cold war illuminations of the classical past: 'The sound and light show' on the Athenian Acropolis. ArtH 244 (2001) 578-97.

Opera, ballet and music

1059 BARKE M, ESCANSY T \& O'HARE G, Samba: a metaphor for Rio's favelas? C 184 (2001) 259-70.

1060 JENNINGS H, The early days of grand opera in Kansas City, 1860-1879. MisHR 95 (2001) 349-71.

1061 TISCHLER BL, Tough times, great tunes: urban jazz and the American experience. JUH 272 (2001) 217-24.

Spectator sports

1062 BARROW J, Chester's earliest regatta? Edgar's Dee-rowing revisited. EmEUR 101 (2001) 81-93.

1063 DIETSCHY P, Une passion urbaine: football et identités dans la première moitié $\mathrm{du}$ vingtième siècle. L'exemple de Turin et de l'Italie, 1890-1940. HUr 3 (2001) 133-47.

1064 PIERCE RB, More than a game: the political meaning of high school basketball in Indianapolis. JUH 271 (2000) 3-23.

1065 SUCHMA P, The selling of Cleveland municipal stadium: the linking of progressive era ideals with the emerging consumer culture. SpHR 31 (2000) 100-19.

1066 ZIEFF SG, From badminton to bolero: sport and recreation in San Francisco's Chinatown, 1895-1950. JSpH 27 (2000) 1-29.

\section{Fine arts}

1067 KENT DV, Cosimo de'medici and the Florentine renaissance: the patron's oeuvre. New Haven/London: Yale UP 2000. pp xiii + 537, il.

\section{Painting}

1068 THOMAS DW, Replicas and originality: picturing agency in Dante Gabriel Rossetti and Victorian Manchester. VS 431 (2001) 67-102.

Sculpture

1069 FINKELSTONE T, The forgotten founder: the statue of Pierre de Laclede Liguest. GaH 21 (2001). 
1070 MCHAM SB, Donatello's David and Judith as metaphors of Medici rule in Florence. ArtB 1 (2001) 32-47.

Other arts

1071 GATOUILLAT F, Les vitraux anciens du séminaire de Caen. AdN 1 (2001) 121-138

\section{Exchange of information}

Newspapers

1072 CARRIERE M, An irresponsible press: Memphis newspapers and the 1866 riot. THQ 60 (2001) 2-15.

1073 DUPUY R ed, Aux origines de la Révolution: journaux et pamphlets à Rennes, 1788-1789. Rennes: UP de Rennes 2001. pp 501.

1074 FURDELL EL, Grub Street commerce: advertisements and politics in the early modern British press. Hist 61 (2001) 35-52.

1075 GOODMAN P comp, Headline Sheffield: the Star brings your past to life. Derby: Breedon 2000. pp 192, il.

1076 KOZLOFF N, Vietnam, the African American community and the Pittsburgh New Courier. Hist 63 (2001) 521-38.

1077 MCKENNA CD, Two strikes and you're out: the demise of the New York Herald Tribune. Hist 63 (2001) 287-308.

1078 NEW YORK POST, The Post's New York: celebrating 200 years of New York City as seen through the pages of the New York Post. New York: Harper Resource 2001.

1079 SIEGEL P, The Fort Wayne Standard: a reform newspaper in the 1850s storm. InMH 97 (2001) 169-89.

Other publications

1080 BANERJI C \& DONALD D eds, Gillray observed, the earliest accounts of his caricatures in London and Paris. Cambridge: Cambridge UP 1999.

Propaganda

1081 STENTON M, Radio London and resistance in occupied Europe: British political warfare, 1939-1943. Oxford: Oxford UP 2000. pp xvi +423.

Libraries, museums and art galleries

1082 SCHELL P, Capturing Chile: Santiago's Museo Nacional during the nineteenth century. JLACS 101 (2001) 45-65.

1083 TAYLOR B, Art for the nation: exhibitions and the London public 1747-2000. New Brunswick, NJ: Rutgers UP 2000.

\section{Education}

1084 BLACK A, Blacks, Jews and the struggle to integrate Brooklyn's junior high school 258: a cold war story. JAEH 20 (2001) 38-69.

1085 CARL J, Harold Washington and Chicago's schools between civil rights and the decline of the New Deal consensus, 1955-1987. HEQ 41 (2001) 311-43.

1086 CAUSEY VE, The long and winding road: school desegregation in Columbus, Georgia, 1963-1997. GHR 85 (2001) 398-434.

1087 CHICKEN E, Chemical education in nineteenth-century Hull. EYH 2 (2001) 38-50.

1088 CHRISTIANSEN LO, Black education in civil war St Louis. MisHR 95 (2001) 302-16.

1089 COMPERE MM \& NOGUES B, La direction d'établissement dans les collèges de l'université de Paris sous l'Ancien Régime. HE 90 (2001) 21-78.

1090 CONDETTE JF, Les enseignants d'histoire et de géographie à la faculté des lettres de Lille sous la Troisième République (1887-1940). RN 339 (2001) 65-100. 
1091 EATON SE, The other Boston busing story: what's won and lost across the boundary line. New Haven: Yale UP 2001.

1092 FISCHER DP ed, Paris 1900. The American school at the universal exposition. New Brunswick, NJ: Rutgers UP 2000.

1093 FULTZ M, Charleston, 1919-1920: the final battle in the emergence of the south's urban African American teaching corps. JUH 275 (2001) 633-49.

1094 KONECNY P, Builders and deserters: students, state, and community in Leningrad, 1917-1941. Montreal/London: McGill-Queen's UP 1999. pp xiii + 358, il.

1095 LE CEEUR M, Les lycées dans la ville: l'exemple parisien (1802-1914). HE 90 (2001) 169-204.

1096 MOSS MS, University, city and state: the University of Glasgow since 1870. Edinburgh: Edinburgh UP 2000.

1097 PADGETT CS, 'Without hysteria or unnecessary disturbance': desegregation of Spring Hill College, Mobile, Alabama, 1948-1954. HEQ 41 (2001) 167-88.

1098 ROUX P, Education et formation des officiers militaires à Toulouse dans la deuxième moitié du XVIIIe siècle. HES 3 (2001) 371-84

1099 SAN MIGUEL G, Brown not white: school integration and the Chicano movement in Houston. College Station: Texas A \& M UP 2001.

1100 STONE CN, HENIG JR, JONES BD \& PIERANNUNZI C, Building civic capacity: the politics of reforming urban schools. Lawrence: UP Kansas 2001.

1101 THEOHARIS JF, 'We saved the city': black struggles for educational equality in Boston, 1960-1976. RHR (2001) 61-94.

1102 URBIEL A, City schools as mirrors of modern urban life. JUH 274 (2001) 511-19.

1103 WECHSLER HS, Access to success in the urban high school: the middle college movement. New York: Teachers College P 2001.

\section{Urban influence on rural areas and the wider world}

1104 LIBERTAI A \& BOUBON F, Ancient Rome: history of a civilization that ruled the world. New York: Barnes and Noble Books 2000.

\section{Attitudes to cities}

1105 ARNOLD D ed, The metropolis and its image: constructing identities for London, c1750-1950. Oxford: Blackwell 1999. pp 176, il.

1106 BERNARD JP, Les deux Paris: essai sur les représentations de Paris dans la seconde moitié du XIXe siècle. Seyssel: Champ Vallon 2001. pp 304.

1107 LOTITO MP, A cidade como espetáculo: publicidade e vida urbana na São Paulo dos anos 20. São Paulo: Annablume 2001.

1108 SCOBEY DM, Empire city: the making and meaning of the New York city landscape. Philadelphia: Temple UP 2001.

1109 TAJBAKHSH K, The promise of the city, space, identity and politics in contemporary social thought. Berkeley: U of California P 2001.

Ancient

1110 DEMOEN K, The Greek city from antiquity to present: historical reality, ideological construction, literary representation. Sterling: Peeters 2001.

1111 MARCHAL GP, De la mémoire communicative à la mémoire culturelle. Le passé dans les témoignages d'Arezzo et de Sienne (1177-1180). AHSS 3 (2001) 563-90.

1112 NEAMINI S, Desaix devant Thèbes. AHRF 324 (2001) 63-8.

1113 TUCK S, Beyond urban identity: Roman imperial coinage, harbor imagery, and the rituals of Adventus. AJA 1052 (2001) 308.

1114 WELCH T, Est locus uni cuique suus: city and status in Horace's Satires 1.8 and 1.9. CA 201 (2001) 165. 
Medieval and early modern (-1800)

1115 AINSWORTH P \& SCOTT T, Regions and landscapes: reality and imagination in late medieval and early modern Europe. Oxford/New York. P Lang 2000.

1116 BELSKY R, The urban ecology of late imperial Beijing reconsidered: the transformation of social space in China's late imperial capital city. JUH 271 (2000) 54-74.

1117 CHATELET-LANGE L, Strasbourg en 1548: le plan Conrad Morant. Strasbourg: UP de Strasbourg 2001. pp 166, il.

1118 DOLAN F, Ashes and the archive: the London fire of 1666, partisanship, and proof. JMEMS 312 (2001) 379-408.

1119 EGLIN J, Venice transfigured: the myth of Venice in British culture, 1660-1797. Basingstoke: Palgrave 2001. pp x + 262, il.

1120 FRIEDMAN D, Fiorenza: geography and representation in a fifteenth-century city view. ZfK 641 (2001) 56-77.

1121 LIGNEREUX Y, L'éloquence des lieux; le pont de la Saône à Lyon en 1635. HUr 3 (2001) 103-18.

1122 MCGOWAN MM, The vision of Rome in late renaissance France. New Haven/London: Yale UP 2000. pp xiii + 461, il.

1123 MERRITT JF ed, Imagining early modern London: perceptions and portrayals of the city from Stow to Strype, 1598-1720. Cambridge: Cambridge UP 2001. pp xii +305.

1124 MILLER N, Mapping the city: the language and culture of cartography in the renaissance. London: Athlone 2001.

1125 MONNET P, Ville réelle et ville idéale à la fin du Moyen Age: une géographie au prisme des témoignages auto-biographiques allemands. AHSS 563 (2001) 591-621.

1126 NIRIT B-AD, Renaissance Florence in the rhetoric of two popular preachers: Giovanni Dominici (1356-1419) and Bernardino da Siena (1380-1444). Turnhout/Cheltenham: Brepols 2001.

1127 PHYTHIAN-ADAMS C, 'Small-scale toy-towns and Trumptons?' Urbanization in Britain and the new Cambridge Urban History. UH 282 (2001) 256-68.

1128 WINTROUB M, L'ordre rituel et l'ordre des choses: l'entrée royale d'Henry II à Rouen. AHSS 2 (2001) 479-506.

Modern (1800-)

1129 ALMANDOZ A, The intelligentsia's two visions of urban modernity: Gómez's Caracas, 1908-35. UH 281 (2001) 84-105.

1130 BUN KM, Order in chaos: Tianjib's hunhunr and urban identity in modern China. JUH 271 (2000) 75-91.

1131 DAVISON G, The European city in Australia. JUH 275 (2001) 779-93.

1132 DERHAM M, How green was my valley? Urban history in Latin America. UH 282 (2001) 278-91.

1133 GUNN S \& MORRIS RJ, Identities in space: contested terrains in the Western city since 1850. Aldershot: Ashgate 2001.

1134 HALL C, Cities of empire. JUH 272 (2001) 193-9.

1135 KUPEL DE, Investigating urban infrastructure. JUH 274 (2001) 520-5.

1136 LEMIRE V, Les puits du ghetto: conflits de mémoire et logiques d'appropriation (Venice, 1450-1650). HUr 4 (2001) 105-26

1137 MELLER H, From Dyos to Daunton: The Cambridge Urban History of Britain, vol. III. UH 282 (2001) 269-77.

1138 NEAD L, Victorian Babylon: people, streets and images in nineteenth-century London. London: Yale UP 2000. pp viii + 251, il.

1139 POWER D, Working and voting for a world class city? A critical viewpoint on the Corporation of London's place in London governance. LJ 2 (2001) 51-64.

1140 ROSSO M, Georgian London revisited. LJ 2 (2001) 35-50.

1141 SCHUYLER D, Revisiting the urban-rural continuum. PenH 68 (2001) 314-24. 
1142 STAPLETON K, SHI M \& MCISAAC ML, The city in modern China. JUH 271 (2000) 50-3.

1143 WHELAN Y, Monuments, power and contested space - the iconography of Sackville Street (O'Connell Street) before independence. IrG 341 (2001) 11-33.

1144 WHELAN Y, Symbolising the state - the iconography of O'Connell Street and environs after independence. $\operatorname{Ir} G 342$ (2001) 135-56.

1145 WHITE DF, Cities in full: the urban south during the final century of the past millennium. AtH 44 (2001) 49-57.

\section{Views of the city in literature, graphic and dramatic art}

1146 GIRAUDY D ed, Marseille au temps de Nadar: exposition Marseille, Musée du vieux Marseille, 2 nov. 2001-31 janv. 2002. Marseille: Parenthèses 2001. pp 124, il.

\section{Literature}

1147 BENNETT JD, Dickens in Leicester. LeiH 37 (2001) 3-5.

1148 CHOI TY, Writing the Victorian city: discourses of risk, connection, and inevitability. VS 434 (2001) 561-90.

1149 DART G, 'Flash style': Pierce Egan and literary London, 1820-28. HWJ 51 (2001) 181-205.

1150 GAILLARD M, Paris au temps de Balzac: l'époque romantique. Etrepally: Presses du Village 2001. pp 206.

1151 MCLAUGHLIN J, Writing the urban jungle: reading empire in London from Doyle to Eliot. Charlottesville: UP of Virginia 2000.

1152 MURPHET J, Literature and race in Los Angeles. Cambridge: Cambridge UP 2001.

1153 PLOTZ J, The crowd, British literature and public politics. Berkeley: U of California P 2000.

Graphic arts

1154 ATGET E, KRASE A \& ADAM HC, Eugène Atget's Paris. Cologne/London: Tascehn 2001. pp 190, il.

1155 CAFFORT M, Sparte et Jérusalem, les davidiens et la peinture religieuse sous la Restauration. RHEF 219 (2001) 415-38.

1156 DE MARÉ E, Victorian London revealed: Gustave Dorés metropolis. London: Penguin Books 2001. pp 228, il.

1157 ELIOT B \& RIOLAND S, Une vue de Rouen en 1525 par Jacques Le Lieur: extrait du Livre des Fontaines. Bonsecours: Point de vues \& Bibliothèque municipale de Rouen 2001. pp 96, il.

1158 FRANK P, Los Artistas del Pueblo and the beginnings of Latin American social realism. TT 53 (2000-2001) 55-68.

1159 LEE AW, Picturing Chinatown: art and Orientalism in San Francisco. Berkeley: U of California P 2001.

1160 LOOKER B, 'Poets of action': the St Louis artists' group, 1968-1972. GaH 22 (2001) $16-27$.

1161 MRAZ J, Photographing Mexico. MexS 171 (2001) 193-211.

1162 SEGRE E, Reframing the city: images of displacement in Mexican urban films of the 1940s and 1950s. JLACS 102 (2001) 205-22. 